\title{
EQUATION OF STATE AND TRANSPORT PROPERTIES OF URANIUM AND PLUTONIUM NITRIDES IN THE LIQUID REGION
} by

A. Sheth and L. Leibowitz Chemical Engineering Division

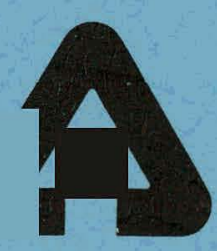

UI G C-ALAA - USERAA

ARGONNE NATIONAL LABORATORY, ARGONNE, ILLINOIS Prepared for the U. S. ENERGY RESEARCH AND DEVELOPMENT ADMINISTRATION under Contract W-31-109-Eng-38 


\section{DISCLAIMER}

This report was prepared as an account of work sponsored by an agency of the United States Government. Neither the United States Government nor any agency Thereof, nor any of their employees, makes any warranty, express or implied, or assumes any legal liability or responsibility for the accuracy, completeness, or usefulness of any information, apparatus, product, or process disclosed, or represents that its use would not infringe privately owned rights. Reference herein to any specific commercial product, process, or service by trade name, trademark, manufacturer, or otherwise does not necessarily constitute or imply its endorsement, recommendation, or favoring by the United States Government or any agency thereof. The views and opinions of authors expressed herein do not necessarily state or reflect those of the United States Government or any agency thereof. 


\section{DISCLAIMER}

Portions of this document may be illegible in electronic image products. Images are produced from the best available original document. 
The facilities of Argonne National Laboratory are owned by the United States Government. Under the terms of a contract (W-31-109-Eng-38) between the U. S. Energy Research and Development Administration, Argonne Universities Association and The University of Chicago, the University employs the staff and operates the Laboratory in accordance with policies and programs formulated, approved and reviewed by the Association.

\section{MEMBERS OF ARGONNE UNIVERSITIES ASSOCIATION}

The University of Arizona

Carnegie-Mellon University

Case Western Reserve University

The University of Chicago

University of Cincinnati

Illinois Institute of Technology

University of Illinois

Indiana University

Iowa State University

The University of Iowa
Kansas State University

The University of Kansas

Loyola University

Marquette University

Michigan State University

The University of Michigan

University of Minnesota

University of Missouri

Northwestern University

University of Notre Dame
The Ohio State University

Ohio University

The Pennsylvania State University

Purdue University

Saint Louis University

Southern Illinois University

The University of Texas at Austin

Washington University

Wayne State University

The University of Wisconsin

\section{NOTICE}

This report was prepared as an account of work sponsored by the United States Government. Neither the United States nor the United States Energy Research and Development Administration, nor any of their employees, nor any of their contractors, subcontractors, or their employees, makes any warranty, express or implied, or assumes any legal liability or responsibility for the accuracy, completeness or usefulness of any information, apparatus, product or process disclosed, or represents that its use would not infringe privately-owned rights. Mention of commercial products, their manufacturers, or their suppliers in this publication does not imply or connote approval or disapproval of the product by Argonne National Laboratory or the U. S. Energy Research and Development Administration. 


$$
\text { ANL-AFP-12 }
$$

Distribution Category: LMFBR Fuels and Materials Engineering and Development (UC-79b)

\section{Argonne National Laboratory}

9700 South Cass Avenue Argonne, Illinois 60439

\section{EQUATION OF STATE AND TRANSPORT \\ PROPERTIES OF URANIUM AND PLUTONIUM NITRIDES \\ IN THE LIQUID REGION}

by

1

A. Sheth and L. Leibowitz

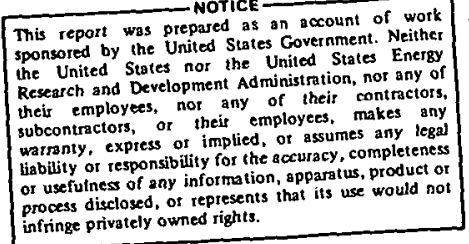

This repont was prepared as an aceonn of Neither Research and Development Administration, nor tactors, theis employes, or their employecs, makes any $y$, express or implithe ot or usefutnes of any infortietion, app its use would aot infringe privately owned rights.

Chemical Engineering Division

October 1975

8 


\section{THIS PAGE \\ WAS INTENTIONALLY \\ LEFT BLANK}




\section{TABLE OF CONTENTS}

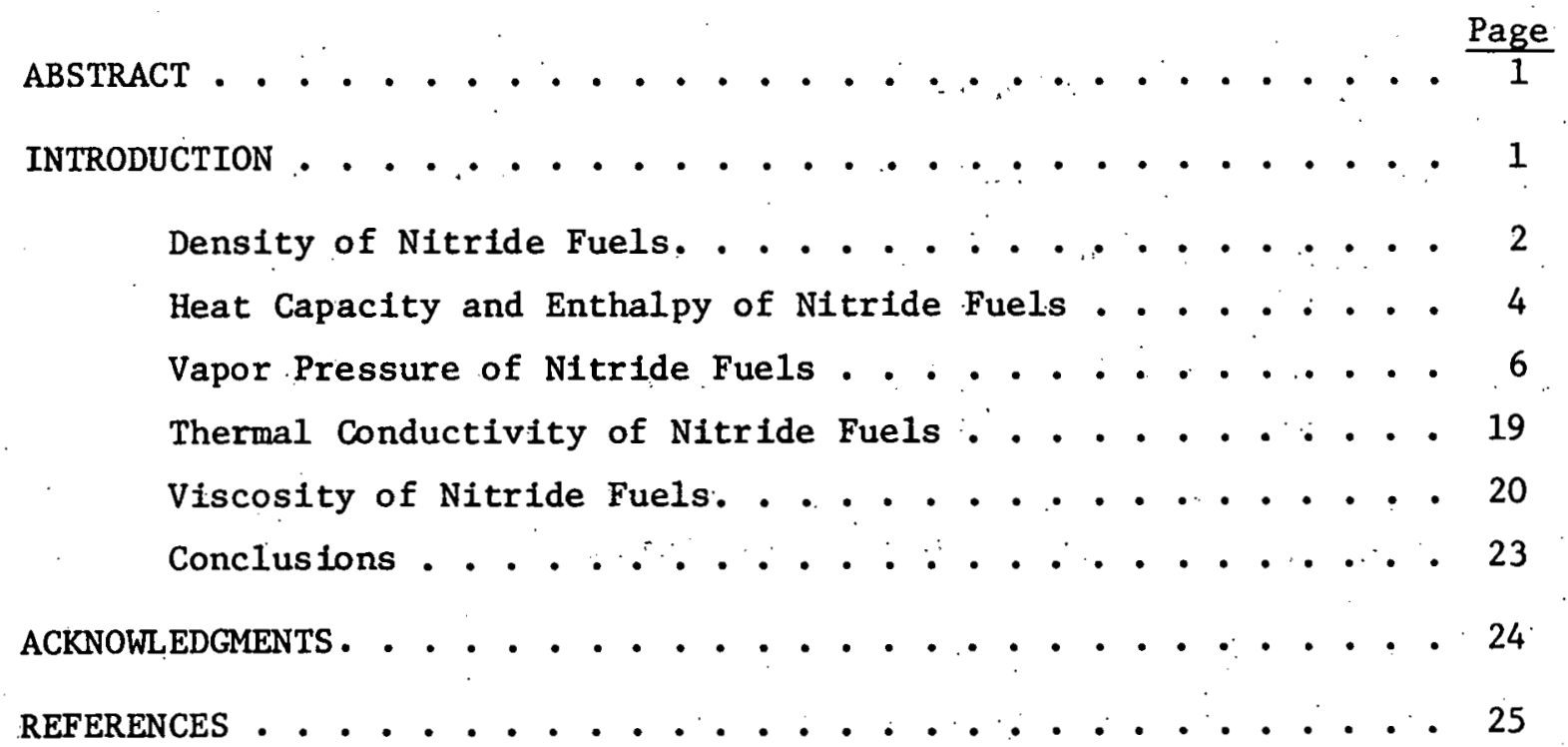




\section{LIST OF FIGURES}

No.

Title

Page

1 Density of Nitride Fuels . . . . . . . . . . . 3

2 Vapor Pressure of Nitride Fuels . . . . . . . . . 20

3 Thermal Conductivity of UN (Below

Melting Polnt)..................... 21

4 Thermal Conductivity of PuN as a Function of Temperature and Density (Below Melting Point). . . . . . . . . 22

5 Thermal Conductivity of $\left(\mathrm{U}_{0.8} \mathrm{Pu}_{0.2}\right) \mathrm{N}$ of $93 \%$

Theoretical Density (Below Melting Point) . . . . . . . 23 


\section{LIST OF TABLES}

No.

Title

$\underline{\text { Page }}$

1 Thermal Expansion of Nitride Fuels . . . . . . . . . 2

2 Recommended Values for Heat Capacity and Enthalpy

of UN Below the Melting Point. . . . . . . ..... 5

3 Recommended Values for Heat Capacity and Enthalpy

of PuN Below the Melting Point . . . . . . . .... 6

4 Recommended Values for Heat Capacity and Enthalpy

of $\left(\mathrm{U}_{0.8} \mathrm{Pu}_{0.2}\right)_{\mathrm{N}}$ Below the Melting Point. . . . . . . . ?

5 Values of Parameters to Calculate Heat Capacity and

Enthalpy at Very High Temperatures . . . . . . . . . 8

6 Estimated Values of Heat Capacity and Enthalpy of

UN in Liquid Region. . . . . . . . . . . . . . . . 9

7 Estimated Values of Heat Capacity and Enthalpy of

PuN in Liquid Region . . . . . . . . . . . . . 10

8 Estimated Values of Heat Capacity and Enthalpy of

$\left(\mathrm{U}_{0.8} \mathrm{Pu}_{0.2}\right)_{\mathrm{N}}$ in Liquid Region. . . . . . . . . . . 11

9 Low-Temperature Vapor Pressure of UN . . . . . . . . . 13

10 Estimated Vapor Pressure of UN . . . . . . . . . . 14

11 Low-Temperature Vapor Pressure of PuN. . . . . . . . . 16

12 Estimated Vapor Pressure of PuN. . . . . . . . . . . . 17

13 Low-Temperature Vapor Pressure of $\left(\mathrm{U}_{0.8} \mathrm{Pu}_{0.2}\right) \mathrm{N} \ldots \ldots$

14 Estimated Vapor Pressure of $\left(\mathrm{U}_{0.8} \mathrm{Pu}_{0.2}\right) \mathrm{N}$ in the 19

15 Thermal Conductivity of Nitride Fuels $(100 \%$
Theoretical Density) . . . . . . . . . . . 23

16 Viscosity of Nitride Fuels . . . . . . . . . . . 24 


\title{
EQUATION OF STATE AND TRANSPORT \\ PROPERTIES OF URANIUM AND PLUTONIUM NITRIDES \\ IN THE LIQUID REGION
}

by

A. Sheth and L. Leibowitz

\begin{abstract}
By' the use of available low-temperature data for various thermophysical and transport properties for uranium and plutonium. nitrides, values above the melting point of density, heat capacity, enthalpy, vapor pressure, thermal conductivity, and viscosity were estimated. Sets of recommended values have been prepared for the compounds $\mathrm{UN}_{3} \mathrm{PuN}$, and $\left(\mathrm{U}_{0.8} \mathrm{Pu}_{0.2}\right) \mathrm{N}$.
\end{abstract}

\section{INTRODUCTION}

In order to improve the performance of breeder reactors, fuels other than oxide fuels are being developed. The advanced fuels currently being considered are carbides and nitrides of uranium and plutonium. These fuels possess better neutronic properties and higher thermal conductivities than oxide fuels. This permits operation of fuel pins at higher linear power ratings and also improves the flexibility of design of the reactor system.

In reactor safety analyses, data are needed on many thermophysical and transport properties of the materials used in reactors. These data are required for temperatures from those of normal operation to $6000^{\circ} \mathrm{C}$ and above. Although adequate data are available at lower temperatures, values for the region of interest to the safety analyst are sparse, and efforts are being made to extrapolate low-temperature data to higher temperatures. The compounds being considered are $U C, U N, P u C, P u N,(U, P u) C$, and $(U, P u) N$. This report describes only the work on nitride fuels. A companion report describing the work on carbide fuels, 1 is being issued.

The properties being extrapolated or estimated by us are heat capacity, enthalpy, density, vapor pressure, thermal conductivity, and viscosity. Alexander and co-workers ${ }^{2}$ discussed emissivity of nitride fuels; since their recommended values were in a good agreement with our recommended values for carbides, 1 we have not discused thio property here.

To obtain self-consistent property values from low-temperatures to the liquid region, we selected low-témperature data from recent critical evaluations by Alexander and co-workers. ${ }^{2}$ In the few cases where no data were available, estimates were made on the basis of similarity or various correlations between related compounds. The estimated or extrapolated data are presented in tables and as equations developed by standard regression techniques. No attempt was made to determine, the optimum form of an equation. The estimated sets of properties values, along with the recommended low-temperature data used, are given below. 
Density of Nitrice Fuels

The density of molten ceramic fuel is an important parameter in safety analyses. No reliable data on the density of liquid nitride fuels are available, and therefore, we have used appropriate literature data on density of solid nitride fuels and the approach that was applied to carbide fuels to derive an equation giving the temperature dependency of the density of the liquid phase. Alexander et $a{ }^{2}{ }^{2}$ recently reviewed the density and thermal expansion data of nitride fuels in the solid state. They gave values for average linear thermal expansion coefficients for $\mathrm{UN}$, PuN, and $\left(\mathrm{U}_{0.8} \mathrm{Pu}_{0.2}\right) \mathrm{N}$ as a function of temperature. Using their data, values were estimated for $\alpha_{s}$ (average linear thermal expansion coefficient in solid) for UN, PuN, and $\left(\mathrm{U}_{0.8} \mathrm{Pu}_{0.2}\right) \mathrm{N}$, from room temperature to these compounds' melting points. Fee and Johnson ${ }^{3}$ recently evaluated melting point data for candidate advanced fuels. In the prcsent rcport, their recommended values are used as melting points for nitride fuels.

In the absence of a reliable value for the volume change on melting $\left(\Delta \mathrm{V} / \mathrm{V}_{\mathrm{S}}\right)$ for nitride fuels, we took the value of $15 \%$, which was estimated for PuN by Alexander et al. ${ }^{2}$ As was done with the carbide fuels on the basis of data for $\mathrm{NaCl}$, the ratio of linear thermal expansion coefficients for the solid and liquid states was assumed to be 0.5 . By use of this ratio, the average values for the thermal expansion coefficient $\left(\alpha_{\ell}\right)$ of the liquid nitrides from the melting point to a higher temperature, $T$, were estimated. Alexander et $a l^{2}{ }^{2}$ have reported the theoretical density of individual nitride fuel, which we assumed to be equal to the density at $298 \mathrm{~K}$. In Table 1 , values for $\alpha_{\mathrm{s}}, \alpha_{\ell}, \mathrm{T}_{\mathrm{m}}$, volume change on melting, and theoretical density for UN, PuN, and $\left(\mathrm{U}_{0.8} \mathrm{Pu}_{0.2}\right) \mathrm{N}$ are listed.

TABT.F 1. Therma1. Fxpansion of Nitride Fuels

\begin{tabular}{cccccc}
\hline Compound & $\begin{array}{c}\alpha_{\mathrm{s}}, \\
\mathrm{cm} /(\mathrm{cm})(\mathrm{K})\end{array}$ & $\begin{array}{c}\alpha_{\ell}, \\
\mathrm{cm} /(\mathrm{cm})(\mathrm{K})\end{array}$ & $\begin{array}{c}\mathrm{T}_{\mathrm{m}}, \\
\mathrm{melting} \text { point, }\end{array}$ & $\begin{array}{c}\Delta \mathrm{V} / \mathrm{v}_{\mathrm{S}}, \\
\%\end{array}$ & $\begin{array}{c}\text { Theoretical } \\
\text { Density at } \\
\mathrm{g} / \mathrm{cm}^{3}{ }^{\circ} \mathrm{C},\end{array}$ \\
\hline $\mathrm{UN}$ & $10.8 \times 10^{-6}$ & $21.6 \times 10^{-6}$ & 3035 & 15 & 14.32 \\
$\mathrm{PuN}$ & $19.5 \times 10^{-6}$ & $39.0 \times 10^{-6}$ & 2843 & 15 & 14.24 \\
$\left(\mathrm{U}_{0.8} \mathrm{Pu}_{0.2}\right) \mathrm{N}$ & $11.4 \times 10^{-6}$ & $22.8 \times 10^{-6}$ & 3053 & 15 & 14.30 \\
\hline
\end{tabular}

To derive the liquid density of nitride fuels, the following equation was used:

$$
\rho_{L}=\frac{\rho_{298}}{1.15\left[1+3\left(T_{m}-298\right) \alpha_{s}\right]\left[I+3\left(T-T_{m}\right) \alpha_{l}\right]} \quad T \geqslant T_{m}
$$


where

$$
\begin{aligned}
& \rho_{\mathrm{L}}=1 \text { iquid density } \mathrm{g} / \mathrm{cm}^{3} \\
& \rho_{2.98}=\text { density at } 25^{\circ} \mathrm{C}, \mathrm{g} / \mathrm{cm}^{3} \\
& \mathrm{~T}=\text { Temperature, } \mathrm{K}
\end{aligned}
$$

By substitution of the values for $\alpha_{s}, T_{m}, \alpha_{l}$, and $\rho_{298}$ from Table 1 and a further simplification, the following equations were obtained:

$$
\begin{aligned}
& \rho_{\mathrm{L}}[\mathrm{UN}]=\frac{14.24}{1+8.07 \times 10^{-5} \mathrm{~T}} \quad \mathrm{~T} \geqslant \mathrm{~T}_{\mathrm{m}} \\
& \rho_{\mathrm{L}}[\mathrm{PuN}]=\frac{16.15}{1+1.75 \times 10^{-4} \mathrm{~T}} \quad \mathrm{~T} \geqslant \mathrm{~T}_{\mathrm{m}} \\
& \rho_{\mathrm{L}}\left[\left(\mathrm{U}_{0.8} \mathrm{Pu}_{0.2}\right) \mathrm{N}\right]=\frac{14.36}{1+8.65 \times 10^{-5} \mathrm{~T}} \quad \mathrm{~T} \geqslant \mathrm{~T}_{\mathrm{m}}
\end{aligned}
$$

The above equations represent our best estimates of the liquid densities of nitride fuels; however, they should be used cautiously to. calculate 1iquid density at temperatures far above the melting point. The value for $a_{\ell}$ may change with temperature, and the method of calculation (assuming the ratio of $\alpha_{s}$ to $\alpha_{l}$ to be equal to 0.5 ) may not be valid at higher temperatures. More-: over, in real situations the chemical compositions of nitride fuels may change, giving rise to unknown effects on density. Density for each of these nitrides is given in Fig. 1 as a function of temperature.

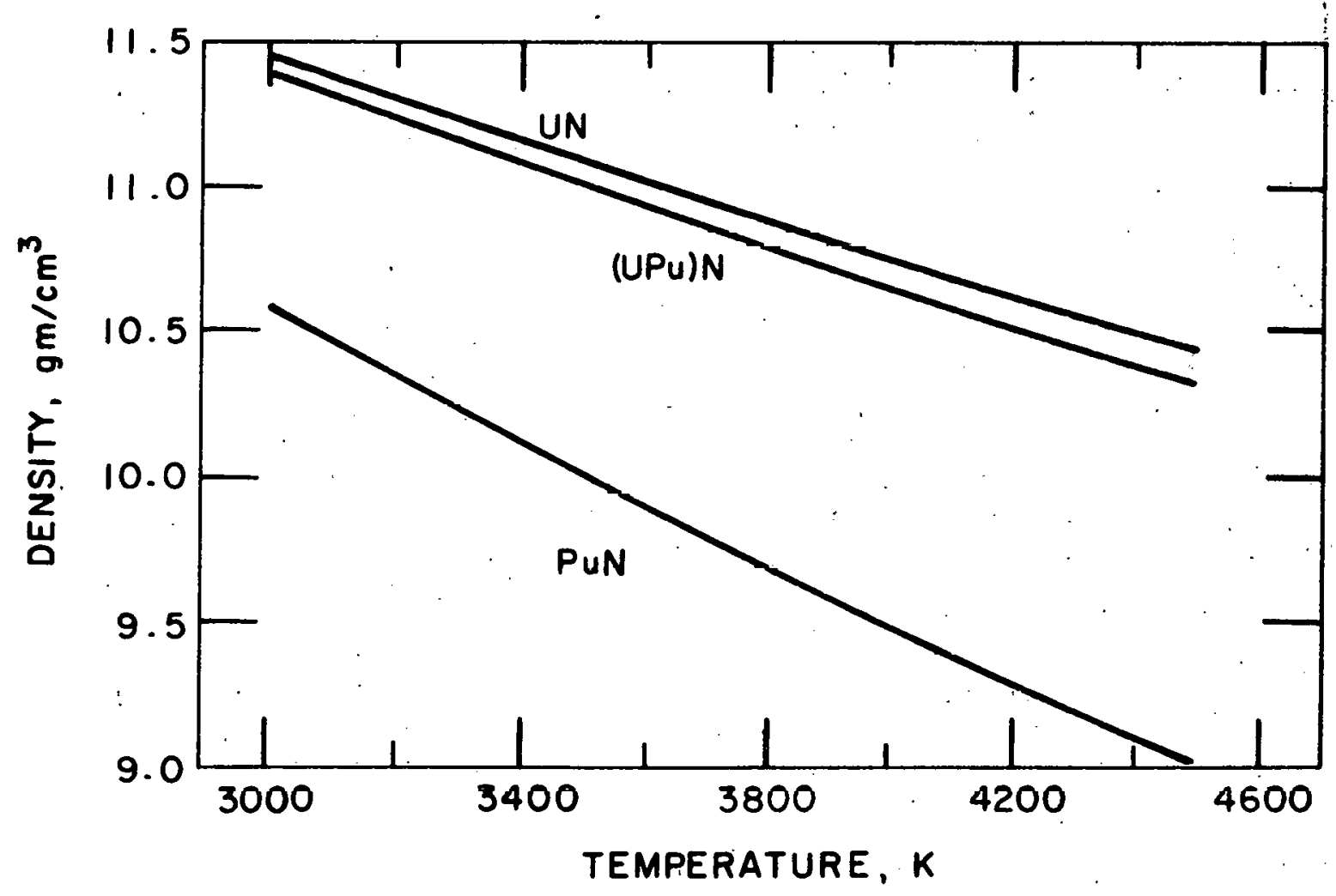

Fig. 1. Density of Nitride Fuels 
Heat Capacity and Enthalpy of Nitride Fuels

The low-temperature heat capacity and enthalpy data for nitrides were taken from the report by Alexander et $a l .{ }^{2}$ for the purpose of extrapolating into the liquid region. The data used were reported up to temperatures near the melting points recommended by Fee and Johnson. ${ }^{3}$ To calculate heat capacity and enthalpy values up to the recommended melting points, we used the equations for $C_{p}^{\circ}$ for the solid region given by Alexander et $a l^{2}{ }^{2}$ These equations may be inconsistent in that $C_{p}^{\circ}$ for mixed nitride is given as lower than both $C_{p}^{\circ}$ [UN] and $C_{p}^{\circ}$ [PuN], whereas it would be expected to be fairly close to the UN values. The differences are small, however, and for the present, we accept the values given in Ref. 2. The values for mixed nitride and for UN are based on measurements, and the PuN heat capacity values are estimated. Enthalpy values were calculated by integration, and the constraint was applied that $\mathrm{H}_{\mathrm{T}}^{\circ}-\mathrm{H}_{298}$ is equal to zero at $298 \mathrm{~K}$. The recommended lowtemperature data with appropriate equations are presented here in Tables 2, 3 , and 4 for $\mathrm{UN}, \mathrm{PuN}$, and $\left(\mathrm{U}_{0.8} \mathrm{Pu}_{0.2}\right) \mathrm{N}$, respectively.

To extrapolate the low-temperature enthalpy data above the melting points, corrections have to be made for the heats of fusion. A thermodynamic approach recommended by Winslow ${ }^{4}$ was used to estimate liquid heat capacity. From basic thermodynamic considerations, one can derive the relation:

$$
C_{p}=C_{v}(1+\gamma \beta T)
$$

where

$$
\begin{aligned}
& C_{p}=\text { heat capacity at constant pressure } \\
& C_{v}=\text { heat capacity at constant volume } \\
& \gamma=\text { Grüneisen constant } \\
& B=\text { volumetric expansion coefficient } \\
& T=\text { Temperature }
\end{aligned}
$$

Winslow ${ }^{5}$ has given the relationship between volumetric expansion coefficient, $\beta$, and defect density, temperature, and other lattice parameters for $\mathrm{UO}_{2}$ and $\mathrm{ThO}_{2}$. However, such information is not available for nitride fuels. Hence, it was decided to follow the same procedure as was used by us for carbide fuels, viz., to calculate $\beta$ from $\alpha_{l}$. Values of the Grüneisen constant, $\gamma$, for most materials lie between 1 and 3 . We have, therefore, taken $\gamma=2$. For $c_{v}$, a value of $3 \mathrm{~K}$ per atom was used, as was done by Winslow. ${ }^{4}$ The value for the heat of fusion $\left(\Delta \mathrm{H}_{f}\right)$ was estimated from the recommended melting point given by Fee and Johnson ${ }^{3}$ and an estimated entropy of fusion equal to $4.2 \mathrm{eu}$, as was used for carbide fuels. Table 5 lists the values of $\gamma, \beta$, $\mathrm{C}_{\mathrm{v}}$, and $\Delta \mathrm{H}_{\mathrm{f}}$ used for nitride fuels in this study.

Usually, as temperature increases, $C_{p}$ values initially increase slowly, but, at a value of the reduced temperature $\left(\mathrm{T}_{\mathrm{r}}=\mathrm{T} / \mathrm{T}_{\mathrm{c}}\right)$ equal to about 0.8 , heat capacities increase very rapidly with increasing temperatures and 
TABLE 2. Recommended Values for Heat Capacity and Enthalpy of UN below the Melting Point ${ }^{2}$

\begin{tabular}{rrrrrl}
\hline $\begin{array}{c}\text { Temp, } \\
\mathrm{K}\end{array}$ & $\begin{array}{c}\mathrm{C}_{\mathrm{p}}^{\circ}, \\
\mathrm{cal} /(\mathrm{mol})(\mathrm{K})\end{array}$ & $\begin{array}{c}\mathrm{H}_{\mathrm{T}}^{\circ}-\mathrm{H}_{298}^{\circ}, \\
\mathrm{cal} / \mathrm{mo1}\end{array}$ & $\begin{array}{c}\text { Temp, } \\
\mathrm{K}\end{array}$ & $\begin{array}{c}\mathrm{C}_{\mathrm{p}}^{\circ}, \\
\mathrm{cal} /(\mathrm{mo1})(\mathrm{K})\end{array}$ & $\begin{array}{c}\mathrm{H}_{\mathrm{T}}^{\circ} \mathrm{H}_{298}^{\circ} \\
\mathrm{ca1} / \mathrm{mol}\end{array}$ \\
\hline 300 & 11.39 & 22 & 1800 & 16.44 & 21458 \\
400 & 12.13 & 1202 & 1900 & 16.70 & 23115 \\
500 & 12.62 & 2441 & 2000 & 16.97 & 24799 \\
600 & 13.00 & $: 3722$ & 2100 & 17.24 & 26509 \\
700 & 13.34 & 5040 & 2200 & 17.51 & 28247 \\
800 & 13.65 & 6390 & 2300 & 17.78 & 30011 \\
900 & 13.95 & 7770 & 2400 & 18.04 & 31802 \\
1000 & 14.24 & 9180 & 2500 & 18.31 & 33620 \\
1100 & 14.52 & 10618 & 2600 & 18.58 & 35464 \\
1200 & 14.80 & 12085 & 2700 & 18.84 & 37335 \\
1300 & 15.08 & 13579 & 2800 & 19.11 & 39233 \\
1400 & 15.35 & 15100 & 2900 & 19.38 & 41157 \\
1500 & 15.62 & 16649 & 3000 & 19.64 & 43108 \\
1600 & 15.90 & 18225 & 3035 & 19.74 & 43798 \\
1700 & 16.17 & 19828 & & & \\
\hline
\end{tabular}

$a_{\text {Recommended data of Alexander et } a \tau^{2}}$

Values are based on:

$$
\begin{aligned}
\mathrm{H}_{\mathrm{T}}^{\circ}-\mathrm{H}_{298}^{\circ} & =-3928.22+11.681 \mathrm{~T}+1.329 \times 10^{-3} \mathrm{~T}^{2}+\frac{9.812 \times 10^{4}}{\mathrm{~T}} \\
\mathrm{C}_{\mathrm{P}}^{0} & =11.681+2.658 \times 10^{-3} \mathrm{~T}-\frac{9.812 \times 10^{4}}{\mathrm{~T}^{2}}
\end{aligned}
$$

approach an infinite value at the critical temperature, $\mathrm{T}_{\mathrm{C}}$. The constant value of $\beta$ used in Eq. 5 will give $C_{p}$ values that are too low at temperatures close to the critical temperature. The critical temperatures for nitrides are not known; however, the same assumption was made as for carbides $\left(\mathrm{T} \cong 3.5 \mathrm{~T}_{\mathrm{m}}\right)$, giving estimated critical temperatures for $\mathrm{UN}$, PuN, and $\left(I_{0.0}^{C} P_{0.2}\right) \mathrm{N}$ of 10620,9950 , and $10690 \mathrm{~K}$, respectively. Based on the above information, we used Eq. 5 and values given in Table 5 to calculate heat capacity and enthalpy data for UN (up to $8500 \mathrm{~K}$ ), for PuN (up to $8000 \mathrm{~K}$ ), and for $\left(\mathrm{U}_{0.8} \mathrm{Pu}_{0.2}\right) \mathrm{N}$ (up to $8600 \mathrm{~K}$ ); these are given in Tables 6,7 , and 8, respectively. 
TABLE 3. Recommended Values for Heat Capacity and Enthalpy of PuN below the Melting Point

\begin{tabular}{cccccc}
\hline $\begin{array}{c}\text { Temp, } \\
\mathrm{K}\end{array}$ & $\begin{array}{c}\mathrm{C}_{\mathrm{p}}^{\circ} \\
\mathrm{cal}(\mathrm{mo1})(\mathrm{K})\end{array}$ & $\begin{array}{c}\mathrm{H}_{\mathrm{T}}^{\circ}-\mathrm{H}_{298}^{\circ}, \\
\mathrm{cal} / \mathrm{mol}\end{array}$ & $\begin{array}{c}\text { Temp } \\
\mathrm{K}\end{array}$ & $\begin{array}{c}\mathrm{C}_{\mathrm{p}}^{\circ} \\
\mathrm{cal} /(\mathrm{mol})(\mathrm{K})\end{array}$ & $\begin{array}{c}\mathrm{H}_{\mathrm{T}}^{\circ}-\mathrm{H}_{298} \\
\mathrm{ca} 1 / \mathrm{mo1}\end{array}$ \\
\hline 300 & $12: 65$ & 25 & 1700 & 16.15 & 20185 \\
400 & 12.90 & 1303 & 1800 & 16.40 & 21813 \\
500 & 13.15 & 2605 & 1900 & 16.65 & 23465 \\
600 & 13.40 & 3933 & 2000 & 16.90 & 25143 \\
700 & 13.65 & 5285 & 2100 & 17.15 & 26845 \\
800 & 13.90 & 6663 & 2200 & 17.40 & 28573 \\
900 & 14.15 & 8065 & 2300 & 17.65 & 30325 \\
1000 & 14.40 & 9493 & 2400 & 17.90 & 32103 \\
1100 & 14.65 & 10945 & 2500 & 18.15 & 33905 \\
1200 & 14.90 & 12423 & 2600 & 18.40 & 35733 \\
1300 & 15.15 & 13925 & 2700 & 18.65 & 37585 \\
1400 & 15.40 & 15453 & 2800 & 18.90 & 39463 \\
1500 & 15.65 & 17005 & 2843 & 19.01 & 40278 \\
1600 & 15.90 & 18583 & &. & \\
\hline
\end{tabular}

${ }^{a}$ Recommended data of Alexander et $a \tau^{2}$

Values are based on:

$$
\begin{aligned}
\mathrm{H}_{\mathrm{T}}^{\circ}-\mathrm{H}_{298}^{\circ} & =-3657.21+11.9 \mathrm{~T}+1.25 \times 10^{-3} \mathrm{~T}^{2} \\
\mathrm{C}_{\mathrm{P}}^{\circ} & =11.9+2.5 \times 10^{-3} \mathrm{~T}
\end{aligned}
$$

By assuming ideal solution behavior, heat capacity data (and by integration of this, enthalpy data) for $\left(\mathrm{U}_{0.8} \mathrm{Pu}_{0 . \dot{2}}\right.$ ) $\mathrm{N}$ were calculated, using data from Tables 6 and 7 . The resulting values agreed within about $\pm 5 \%$ with the values given in Table 8 .

\section{Vapor Pressure of Nitride Fuels}

Consideration of the vapor pressure over nitride fuel material is complicated because of the various gaseous species that may exist over the solid and liquid. Moreover, Alexander et al. ${ }^{2}$ report, "plutonium nitride can vaporize congruently while uranium nitride cannot; and this difference is caused by the much higher vapor pressure of plutonium as compared to uranium." The measurements in the low-temperature region are not complete, and considerable estimation and speculation are needed to derive vapor pressure values. ${ }^{2}$ This makes high-temperature extrapolation and estimation particularly difficult. 
TABLE 4. Recommended Values for Heat Capacity and Enthalpy of $\left(\mathrm{U}_{0.8} \mathrm{Pu}_{0.2}\right) \mathrm{N}$.below the Melting Point ${ }^{\mathrm{a}}$

\begin{tabular}{|c|c|c|c|c|c|}
\hline$\underset{\mathrm{K}}{\text { Temp, }}$ & $\stackrel{\mathrm{C}_{\mathrm{p}}^{\circ},}{\mathrm{cal} /(\mathrm{mol})(\mathrm{K})}$ & $\begin{array}{l}\mathrm{H}_{\mathrm{T}}^{\circ}-\mathrm{H}_{298}^{\circ}, \\
\mathrm{cal} / \mathrm{mol}\end{array}$ & $\underset{\mathrm{K}}{\mathrm{Temp}}$ & $\begin{array}{c}\mathrm{C}_{\mathrm{p}}^{\circ}, \\
\operatorname{cal} /(\mathrm{mo1})(\mathrm{K})\end{array}$ & $\begin{array}{l}\mathrm{H}_{\mathrm{T}}^{\circ}-\mathrm{H}_{298}^{\circ} \\
\mathrm{cal} / \mathrm{mol}\end{array}$ \\
\hline 300 & 11.62 & 23 & 1800 & 15.52 & 20378 \\
\hline 400 & 11.88 & 1198 & 1900 & 15.78 & 21943 \\
\hline 500 & 12.14 & 2399 & 2000 & 16.04 & 23534 \\
\hline 600 & 12.40 & 3626 & 2100 & 16.30 & 25151 \\
\hline 700 & 12.66 & 4879 & 2200 & 16.56 & 26794 \\
\hline 800 & 12.92 & 6158 & 2300 & 16.82 & 28463 \\
\hline 900 & 13.18 & 7463 & 2400 & 17.08 & 30158 \\
\hline 1000 & 13.44 & 8794 & 2500 & 17.34 & 31879 \\
\hline 1100 & 13.70 & 10151 & 2600 & 17.60 & 33626 \\
\hline 1200 & 13.96 & 11534 & 2700 & 17.86 & 35399 \\
\hline 1300 & 14.22 & 12943 & 2800 & 18.12 & 37198 \\
\hline 1400 & 14.48 & 14378 & 2900 & 18.38 & 39023 \\
\hline 1500 & 14.74 & 15839 & 3000 & 18.64 & 40874 \\
\hline 1600 & 15.00 & 17326 & 3053 & 18.78 & 41866 \\
\hline 1700 & 15.26 & 18839 & & & \\
\hline
\end{tabular}

${ }^{a}$ Recommended data of Alexander et $a l^{2}$

Values are based on:

$$
\begin{aligned}
\mathrm{H}_{\mathrm{T}}^{\circ}-\mathrm{H}_{298}^{\circ} & =-3345.8+10.84 \mathrm{~T}+1.3 \times 10^{-3} \mathrm{~T}^{2} \\
\mathrm{C}_{\mathrm{p}}^{\circ} & =10.84+2.6 \times 10^{-3} \mathrm{~T}
\end{aligned}
$$

The we11-known law of corresponding states has been used to estimate high-temperature thermodynamic properties. This has been used by several investigators to estimate first the critical properties of reactor fuel materials and then their vapor pressures by using the generalized vapor pressure correlations given by Hougen, Watson, and Ragatz. ${ }^{6}$ Miller ${ }^{7}$ has given a detailed report on various empirical and semitheoretical approaches reported in the literature for estimation of vapor pressures.

Low-temperature vapor pressure data are very sensitive to the details of stoichiometry, pressure, and the materials of containment used for the experiment. For reactor safety analyses, these data must of ten be extrapolated six to nine orders of magnitude or higher in pressure than that experimentally measured. In such extrapolations, there is always a danger that vapor species which may be important at high temperatures 
TABLE 5. Values of Parameters to Calculate Heat Capacity and Enthalpy at Very High Temperatures

\begin{tabular}{lccc}
\hline Parameter & UN & PuN & $\left(\mathrm{U}_{0.8} \mathrm{Pu}_{0.2}\right) \mathrm{N}$ \\
\hline$\gamma$ & 2 & 2 & 2 \\
$\mathrm{~B}$ & $6.48 \times 10^{-5}$ & $1.71 \times 10^{-4}$ & $6.84 \times 10^{-5}$ \\
$\mathrm{C}_{\mathrm{v}}^{\mathrm{a}}$ & $6 \mathrm{R}$ & $6 \mathrm{R}$ & $6 \mathrm{R}$ \\
$\Delta \mathrm{H}_{\mathrm{f}}$, kcal/mol & 12.75 & 11.94 & 12.59 \\
\hline $\mathrm{a}_{\mathrm{R}}$ is the gas constant & & &
\end{tabular}

may not be adequately represented by the lower temperature data. The approach that we have taken is to derive from basic thermodynamic data, equations for the pressures of individual vapor species, to extrapolate the equations, and to sum the pressures to give the total pressure above the condensed phase. For extrapolations above the melting point, adjustment is required for the heat of fusion. Following a suggestion of Blackburn, ${ }^{8}$ we have corrected each partial pressure equation by a multiple of the heat of fusion $\left(\Delta \mathrm{H}_{f}\right)$. The multiple depends on the number of condensed-phase molecules required to form the gaseous molecule; $e . g$. , $\Delta \mathrm{H}_{\mathrm{f}}$ for $\mathrm{U}(\mathrm{g}), 2 \Delta \mathrm{H}_{\mathrm{f}}$ for $\mathrm{N}_{2}(\mathrm{~g}), 2 \Delta \mathrm{H}_{\mathrm{f}}$ for $\mathrm{Pu}_{2}(\mathrm{~g})$, etc. This method was also applied to carbide fuels and gave reasonable results. Since the partial pressure of each species is extrapolated, equal consideration is given to each species. In this way, species less dominant at lower temperatures are given proper weight at higher temperatures.

In the recent critical evaluation of low-temperature vapor pressure data of $\mathrm{UN}$, Alexander et $a l^{2}{ }^{2}$ reported that the evaporation coefficient of uranium, $\alpha_{V}$, lies between 0.3 and 1.0 and that the evaporation coefficient for nitrogen is much lower (being of the order of 0.01). Because of these values, Alexander and co-workers ${ }^{2}$ showed that while UN appears to vaporize congruently at temperatures to $2000 \mathrm{~K}$, this congruency may be the result of kinetics, not thermodynamics. Therefore, for practical purposes, vaporization of UN can be considered incongruent vaporization by preferential loss of nitrogen to form a two-phase system comprising nitrogen-saturated liquid uranium and uranium-saturated nonstoichiometric uranium.mononitride. In such a case, increasing the temperature of a stolchiometric un sample is certain to yield substoichiometric UN due to incongruent vaporization. Study of the phase equilibrium of UN is not yet complete, and beyond the: melting point (or decomposition temperature) of UN, the system is not well understood. It was decided by us to use the data of Gingerich, 9 who investigated, by the Knudsen effusion technique in combination with a mass spectrometer, the two-phase region of $U(l)+U N(s) \cdot$ He expressed the overall vaporization reaction of uranium-saturated uranium mononitride 
TABLE 6. Estimated Values of Heat Capacity and Enthalpy of UN in Liquid Region

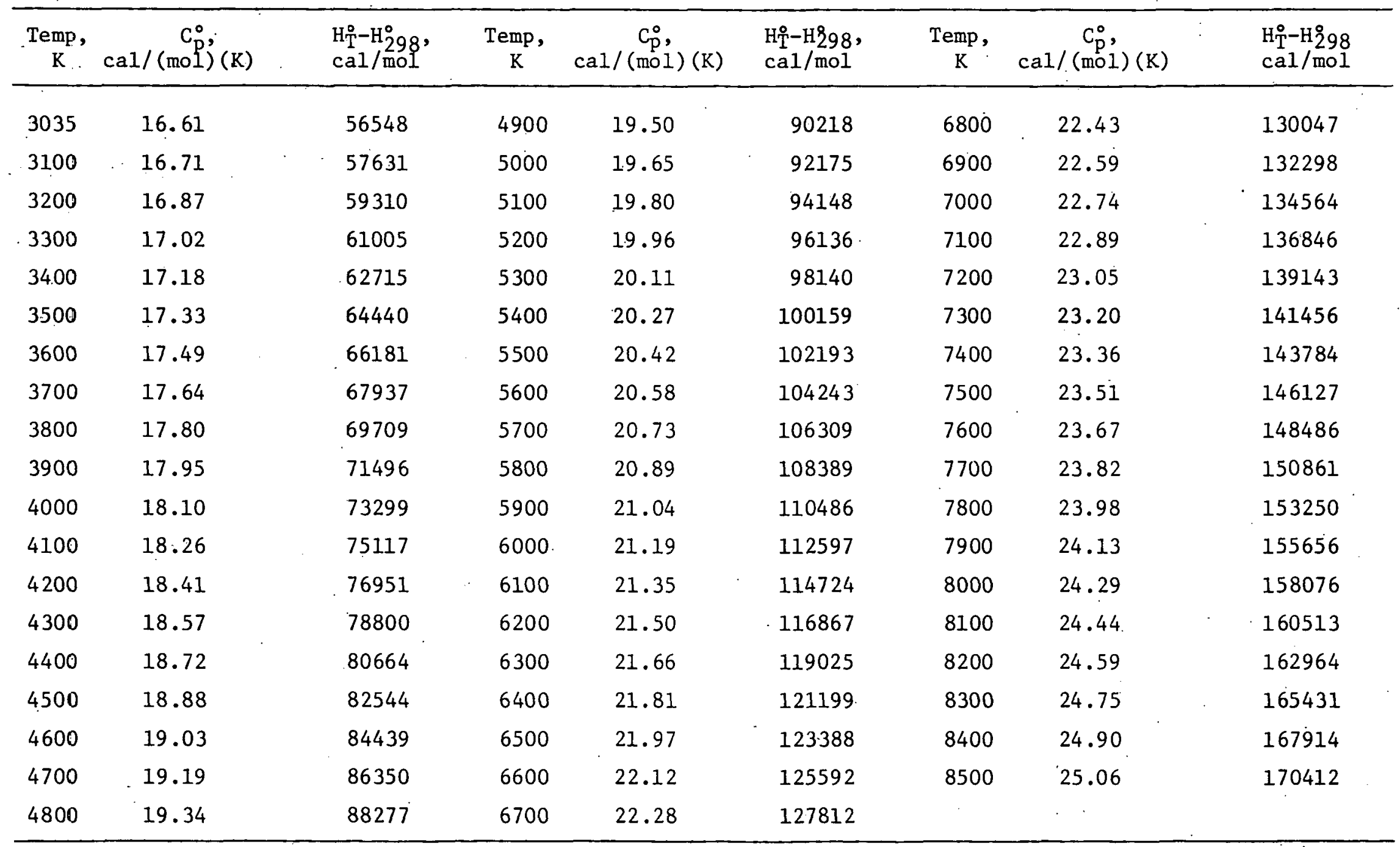

Values are based on:

$$
\begin{aligned}
\mathrm{C}_{\mathrm{p}}^{\circ} & =11.9232+1.5452 \times 10^{-3} \mathrm{~T} \\
\mathrm{H}_{\mathbf{T}}^{\circ}-\mathrm{H}_{298}^{0} & =15244.5+11.9232 \mathrm{~T}+7.726 \times 10^{-4} \mathrm{~T}^{2}
\end{aligned}
$$


TABLE 7. Estimated Values of Heat Capacity and Entha-py of PuN in Liquid Regicn

\begin{tabular}{|c|c|c|c|c|c|c|c|c|c|c|}
\hline $\begin{array}{c}\text { Temp, } \\
\cdot \mathrm{K}\end{array}$ & $\begin{array}{c}\mathrm{C}_{\mathrm{p}}^{\circ}, \\
\mathrm{cal} /(\mathrm{mo})(\mathrm{K})\end{array}$ & & $\begin{array}{l}\mathrm{H}_{\mathrm{T}}^{\circ}-\mathrm{H}_{298}^{\circ}, \\
\mathrm{cal} / \mathrm{mol}\end{array}$ & $\stackrel{\mathrm{T}}{\mathrm{Temp}}$ & $\begin{array}{c}\mathrm{C}_{\mathrm{p}}^{\circ}, \\
\mathrm{cal} /(\mathrm{mol})(\mathrm{K})\end{array}$ & $\begin{array}{l}\mathrm{H}_{\mathrm{T}}^{\circ}-\mathrm{H} 298, \\
\mathrm{cal} / \mathrm{mol}\end{array}$ & $\begin{array}{c}\text { Temp, } \\
\mathrm{K}\end{array}$ & $\begin{array}{c}\mathrm{C}_{\mathrm{p}}^{\circ} \\
\mathrm{cal} /(\mathrm{mol})(\mathrm{K})\end{array}$ & $\ddots$ & $\begin{array}{l}\mathrm{H}_{\mathrm{T}}^{\circ}-\mathrm{H}_{298}^{298} \\
\mathrm{cal} / \mathrm{mol}\end{array}$ \\
\hline 2843 & 19.86 & & 52218 & 4600 & 24.76 & 91410 & 6400 & 29.78 & & 140493 \\
\hline 2900 & 20.01 & & 53354 & 4700 & 25.04 & 93900 & 6500 & 30.06 & & 143485 \\
\hline 3000 & 20.29 & & 55370 & 4800 & 25.32 & 96417 & 5600 & 30.34 & & 146504 \\
\hline 3100 & 20.57 & & 57413 & 4900 & 25.59 & 98963 & 5700 & 30.62 . & & 14955.2 \\
\hline 3300 & 21.13 & & 61583 & 5100 & 26.15 & 104137 & 5900 & 31.17 & & 155731 \\
\hline 3400 & 21.41 & & 63710 & 5200 & 26.43 & 106766 & 7000 & 31.45 & & 158862 \\
\hline 3500 & 21.69 & & 65865 & 5300 & 26.71 & 109424 & 7100 & 31.73 & & 162022 \\
\hline 3600 & 21.97 & & 68048 & 5400 & 26.99 & 112109 & 7200 & 32.01 & & 165209 \\
\hline 4000 & 23.08 & & 77058 & 5800 & 28.11 & 123127 & 7600 & $32: 13$ & & 178237 \\
\hline .4100 & 23.36 & & 79380 & 5900 & 28.38 & 125952 & .7700 & 33.41 . & & 181563 \\
\hline 4200 & 23.64 & & 81730 & 6000 & 28.66 & 128804 & 7800 & 33.69 & & 184918 \\
\hline .4300 & 23.92 & & 84108 & 6100 & 28.94 & 131685 & 7900 & 33.96 & & 188300 \\
\hline 4400 & 24.20 & & 86514 & 6200 & 29.22 & 134593 & 8000 & 34.24 & & 19.1711 \\
\hline 4500 & 24.48 & & 88948 & 6300 & 29.50 & 137529 & & & & \\
\hline
\end{tabular}

Values are based on:

$$
\begin{aligned}
\mathrm{C}_{\mathrm{p}}^{\circ} & =11.9232+2.79 \times 10^{-3} \mathrm{~T} \\
\mathrm{H}_{\mathrm{T}}^{\circ}-\mathrm{H}_{298}^{\circ} & =7045+11.9232 \mathrm{~T}+1.395 \times 10^{-3} \mathrm{~T}^{2}
\end{aligned}
$$


TABLE 8. Estimated Values of Heat Capacity and Enthalpy of $\left(\mathrm{U}_{0.8} \mathrm{Pu}_{0.2}\right)_{\mathrm{N}}$ in Liquid Region

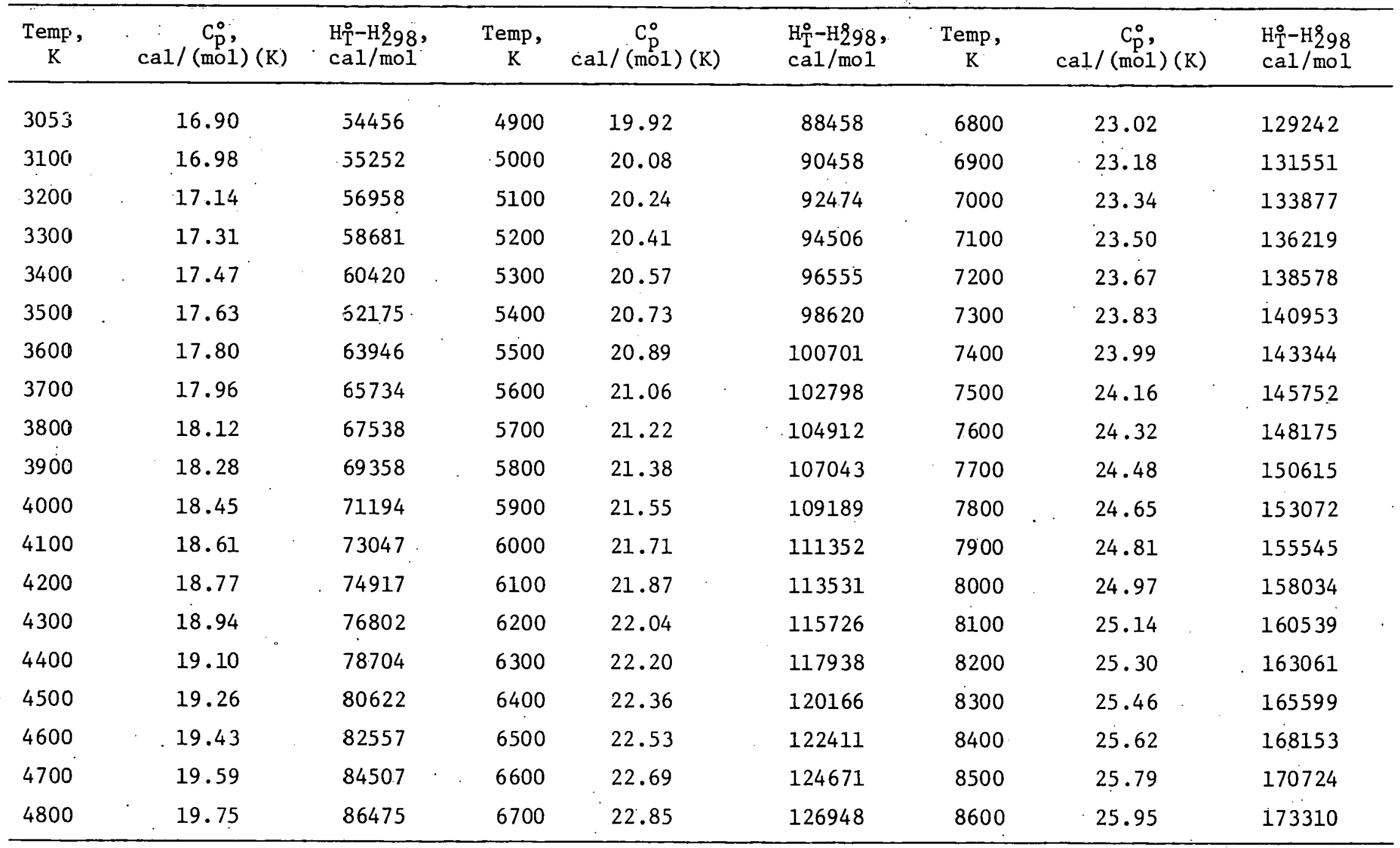

Values are based on:

$$
\begin{aligned}
\mathrm{C}_{\mathrm{p}}^{\circ} & =11.9232+1.6311 \times 10^{-3} \mathrm{~T} \\
\mathrm{H}_{\mathrm{T}}^{\circ}-\mathrm{H}_{298}^{\circ} & =10452.9+11.9232 \mathrm{~T}+8.1555 \times 10^{-4} \mathrm{~T}^{2}
\end{aligned}
$$


by the expression

$$
\mathrm{UN}\left[\mathrm{UN}_{\mathrm{y}}(\mathrm{s})\right]=\mathrm{U}(\mathrm{g})+0.5 \mathrm{~N}_{2}(\mathrm{~g})
$$

where $\mathrm{y}$ is a parameter designating the temperature dependence of the uraniumsaturated solid UN phase which is in equilibrium with nitrogen-saturated 1iquid uranium. The corresponding partlal reaction for the formation of 0.5 mole of $\mathrm{N}_{2}(\mathrm{~g})$ was expressed by the equation

$$
\mathrm{UN}\left[\mathrm{UN}_{\mathrm{y}}(\mathrm{s})\right]=\mathrm{UN}\left[\mathrm{UN}_{\mathrm{h}}(\ell)\right]+0.5 \mathrm{~N}_{2}(\mathrm{~g})
$$

and the partial reaction for the formation of 1 mole of $U(g)$ was given as:

$$
\mathrm{U}\left[\mathrm{UN}_{\mathrm{h}}(l)\right]=\mathrm{U}(\mathrm{g})
$$

In Eqs. 7 and 8, $\mathrm{UN}_{\mathrm{h}}(l)$ represented nitrogen-containing 1iquid uranium that is in equilibrium with nitrogen-deficient UN phase, where $h$ is a temperature-dependent term. At lower temperatures, the reaction represented by Eq. 7 is dominant over the reaction represented by Eq. 8 and there is a continuous shift in the $\mathrm{N} / \mathrm{U}$ atomic ratio toward lower values as vaporization proceeds. From his experimental work, Gingerich ${ }^{9}$ gave the following equations representing partial pressures of $\mathrm{U}$ and $\mathrm{N}_{2}$ in the two-phase region of $\mathrm{U}(\ell)+\mathrm{UN}(\mathrm{s}):$

$$
\begin{aligned}
& \log \mathrm{P}_{U}(\mathrm{~atm})=5.825-\frac{26854}{\mathrm{~T}} \\
& \log \mathrm{P}_{\mathrm{N}_{2}}(\mathrm{~atm})=8.904-\frac{30464}{\mathrm{~T}}
\end{aligned}
$$

In a number of experiments at Battelle, 10 gaseous UN was observed experimentally. In the absence of precise measurement of $U N(g)$ species, Alexander and co-workers ${ }^{2}$ made some estimates and suggested the following vapor pressure equation:

$$
\log \mathrm{P}_{\mathrm{UN}}(\mathrm{atm})=8.39-\frac{38200}{\mathrm{~T}}
$$

A series of experiments were directed toward the observation of gaseous $\mathrm{U}_{2}$ at Battelle Columbus Laboratory. ${ }^{2}$ at no time was the dimer observed, even with uranium pressures as high as $10^{-4}$ atm in an effusion ceil mass spectrometer. Based on this, Alexander et $a l^{2}{ }^{2}$ suggested that gaseous $\mathrm{U}_{2}$ is of little concern, even in safety analysis work at very high temperature.

From Eqs. 9, 10, and 11, the total pressure, $\mathrm{P}_{\mathrm{T}}$, was determined by extrapolating Gingerich's data up to the melting point of UN and summing all partial pressures (i.e., $\mathrm{P}_{\mathrm{T}}=\mathrm{P}_{\mathrm{U}}+\mathrm{P}_{\mathrm{N}_{2}}+\mathrm{P}_{\mathrm{UN}}$ ) to obtain low-temperature (1900-3000 K) vapor pressure data. These are given in Table 9.

Fitting the standard form of the vapor pressure versus temperature relation to the total pressure data given in Table 9 yields the following equation:

$$
\begin{aligned}
& \log \mathrm{P}_{\mathrm{T}}=6.4351-\frac{29695}{\mathrm{~T}}+0.6386 \log \mathrm{T} \\
& \left(\mathrm{P}_{\mathrm{T}} \text { in atm, } \mathrm{T} \text { in } \mathrm{K}\right)
\end{aligned}
$$


TABLE 9. Low-Temperature Vapor Pressure of UN

\begin{tabular}{ccccc}
$\begin{array}{c}\text { Temp, } \\
\mathrm{K}\end{array}$ & $\begin{array}{c}\mathrm{P}_{\mathrm{U}}, \\
\mathrm{atm}\end{array}$ & $\begin{array}{c}\mathrm{P}_{\mathrm{N}_{2}}, \\
\mathrm{~atm}\end{array}$ & $\begin{array}{c}\mathrm{P}_{\mathrm{UN}}, \\
\mathrm{atm}\end{array}$ & $\begin{array}{c}\mathrm{P}_{\mathrm{T}}= \\
\text { Total Pressure, } \\
\mathrm{atm}\end{array}$ \\
\hline 1900 & $4.91 \times 10^{-9}$ & $7.42 \times 10^{-8}$ & $1.93 \times 10^{-12}$ & $7.91 \times 10^{-8}$ \\
2000 & $2.50 \times 10^{-8}$ & $4.70 \times 10^{-7}$ & $1.95 \times 10^{-11}$ & $4.95 \times 10^{-7}$ \\
2100 & $1.09 \times 10^{-7}$ & $2.50 \times 10^{-6}$ & $1.58 \times 10^{-10}$ & $2.61 \times 10^{-6}$ \\
2200 & $4.16 \times 10^{-7}$ & $1.14 \times 10^{-5}$ & $1.06 \times 10^{-9}$ & $1.18 \times 10^{-5}$ \\
2300 & $1.41 \times 10^{-6}$ & $4.56 \times 10^{-5}$ & $6.04 \times 10^{-9}$ & $4.70 \times 10^{-5}$ \\
2400 & $4.32 \times 10^{-6}$ & $1.62 \times 10^{-4}$ & $2.97 \times 10^{-8}$ & $1.67 \times 10^{-4}$ \\
2500 & $1.21 \times 10^{-5}$ & $5.23 \times 10^{-4}$ & $1.29 \times 10^{-7}$ & $5.35 \times 10^{-4}$ \\
2600 & $3.14 \times 10^{-5}$ & $1.54 \times 10^{-3}$ & $4.99 \times 10^{-7}$ & $1.57 \times 10^{-3}$ \\
2700 & $7.57 \times 10^{-5}$ & $4.18 \times 10^{-3}$ & $1.75 \times 10^{-6}$ & $4.26 \times 10^{-3}$ \\
2800 & $1.72 \times 10^{-4}$ & $1.06 \times 10^{-2}$ & $5.59 \times 10^{-6}$ & $1.08 \times 10^{-2}$ \\
2900 & $3.67 \times 10^{-4}$ & $2.51 \times 10^{-2}$ & $1.65 \times 10^{-5}$ & $2.55 \times 10^{-2}$ \\
3000 & $7.48 \times 10^{-4}$ & $5.62 \times 10^{-2}$ & $4.54 \times 10^{-5}$ & $5.69 \times 10^{-2}$ \\
\hline
\end{tabular}

In the absence of low-temperature data for single-phase. UN, the data from the two-phase study of Gingerich ${ }^{9}$ were extrapolated to the liquid region, and represent a higher limit. Since with increasing temperature, the $\mathrm{N} / \mathrm{U}$ atom ratio shifts towards lower values, substoichiometric UN will have lower vapor pressures than that calculated by mere extrapolation. In the absence of any information on how and to what extent this substoichiometry affects the results, it is recommended that the following data (the extrapolation to the liquid region) should be used with care.

At temperatures above the melting point, one must correct the equation representing the vapor pressure for the heat of fusion in order to extrapolate total pressure over UN into the liquid region. As mentioned above, according to $B l a c k b u r n,{ }^{8}$ a reasonable approach is to correct the slope of the partial pressure curve of each species by an appropriate multiple of the heat of fusion of UN at the melting point and then to use the corrected equation to extrapolate beyond the melting point. The corrected equations for the liquid region are as follows:

$$
\begin{aligned}
\log \mathrm{P}_{U} & =4.91-\frac{24100}{\mathrm{~T}} \\
\log \mathrm{P}_{\mathrm{N}_{2}} & =7.07-\frac{24900}{\mathrm{~T}} \\
\log \mathrm{P}_{\mathrm{UN}} & =7.47-\frac{35400}{\mathrm{~T}}
\end{aligned}
$$


By use of the above equations and the relation

$$
\text { Total pressure }=\mathrm{P}_{\mathrm{T}}=\mathrm{P}_{\mathrm{U}}+\mathrm{P}_{\mathrm{N}_{2}}+\mathrm{P}_{\mathrm{UN}}
$$

we calculated values for various partial pressures and total pressures as a function of temperature. These are given in Table 10.

TABLE 10. Estimated Vapor Pressure of UN

\begin{tabular}{ccccc}
\hline $\begin{array}{c}\text { Temp, } \\
\mathrm{K}\end{array}$ & $\begin{array}{c}\mathrm{P}_{\mathrm{U}}, \\
\mathrm{atm}\end{array}$ & $\begin{array}{c}\mathrm{P}_{\mathrm{N}_{2}}, \\
\mathrm{~atm}\end{array}$ & $\begin{array}{c}\mathrm{P}_{\mathrm{UN}}, \\
\mathrm{atm}\end{array}$ & $\begin{array}{c}\mathrm{P}_{\mathrm{T}}= \\
\text { Total Pressure, } \\
\mathrm{atm}\end{array}$ \\
\hline 3100 & $1.39 \times 10^{-3}$ & 0.11 & $1.12 \times 10^{-4}$ & 0.11 \\
3500 & $1.07 \times 10^{-2}$ & 0.90 & $2.26 \times 10^{-3}$ & 0.92 \\
4000 & $7.76 \times 10^{-2}$ & 7.00 & $4.15 \times 10^{-2}$ & 7.12 \\
4500 & 0.36 & 34.39 & 0.40 & 35.15 \\
5000 & 1.24 & 122.89 & 2.45 & 126.58 \\
5500 & 3.40 & 348.39 & 10.79 & 362.58 \\
6000 & 7.86 & 830.23 & 37.13 & 875.22 \\
6500 & 16.00 & 1731.1 & 105.61 & 1852.7 \\
7000 & 29.43 & 3249.7 & 258.74 & 3537.9 \\
7500 & 49.88 & 5609.2 & 562.51 & 6221.6 \\
8000 & 79.16 & 9043.3 & 1109.8 & 10232.0 \\
\hline
\end{tabular}

The equation correlating total vapor pressure over UN with temperature in the liquid region is:

$$
\begin{aligned}
& \log \mathrm{P}_{\mathrm{T}}=4.9968-\frac{24048}{\mathrm{~T}}+0.51735 \log \mathrm{T} \\
& \left(\mathrm{P}_{\mathrm{T}} \text { in atm, } \mathrm{T} \text { in } \mathrm{K}\right)
\end{aligned}
$$

From the values given in Table 10, the boiling point at standard conditions of UN was calculated to be $3520 \mathrm{~K}$.

In their low-temperature cvaluation of nitride fuclo, $\Lambda$ lerander and co-workers ${ }^{2}$ reported that plutonium nitride can vaporize congruently, which required that the number of moles of plutonium vaporizing per unit time be exactly twice the molar rate of nitrogen vaporizing. Numerically, this means that $\mathrm{PPu}_{\mathrm{Pu}} / \mathrm{P}_{\mathrm{N}_{2}}=5.8$. By the use of free energy of formation data for various species from the literature and the above constraint, partial pressures of plutonium and nitrogen were calculated. These partial pressures agreed with those calculated from the equations recommended by Sheth and Leibowitz ${ }^{11}$ within a factor of two. Since the equations recommended by Sheth and Leibowitz ${ }^{11}$ were arrived at by fitting the standard equations to the 
experimental data of Kent, ${ }^{12}$ Battelle Memorial Institute, 1 3, 14 and Rand, 15 it was decided to use the equations of Sheth and Leibowitz for extrapolation into the liquid region. For the partial pressures of plutonium and nitrogen these equations are as follows:

$$
\begin{aligned}
& \log \mathrm{P}_{\mathrm{Pu}}=5.9863-\frac{21056}{\mathrm{~T}} \\
& \log \mathrm{P}_{\mathrm{N}_{2}}=5.2125-\frac{20967}{\mathrm{~T}}
\end{aligned}
$$

Alexander et $a l^{2}$ indicated that partial pressure of $\mathrm{PuN}(\mathrm{g})$ is of more significance than partial pressure of $\mathrm{UN}(\mathrm{g})$ at elevated temperatures. From their estimate of standard dissociation energy ( $\left.D_{\circ}^{\circ}\right)$ for PuN, they recommended the following equation for the partial pressure of $\mathrm{PuN}(\mathrm{g})$ :

$$
\log \mathrm{P}_{\mathrm{PuN}}=8.30-\frac{30600}{\mathrm{~T}}
$$

Alexander and co-workers ${ }^{2}$ also estimated the standard dissociation energy, $\mathrm{D}_{0}^{\circ}$, for $\mathrm{Pu}_{2}$. According to them, at the melting point of PuN, the dimer concentration could reach a few percent of the pressure of monomeric plutonium. Hence, for equation-of-state calculations, they recommended the inclusion of $\mathrm{Pu}_{2}$. From basic thermodynamic principles and estimated values for pertinent thermodynamic parameters, the following equation was derived for partial pressure of $\mathrm{Pu}_{2}$ below the melting point of PuN:

$$
\log \mathrm{P}_{\mathrm{Pu}_{2}}=7.27-\frac{30300}{\mathrm{~T}}
$$

By the use of Eqs. 18, 19, 20, and 21, the partial pressures of various species over PuN were calculated from 1600 to $2800 \mathrm{~K}$. Total pressure, $\mathrm{P}_{\mathrm{T}}$, was obtained by summing all partial pressure terms. For temperatures below the melting point, Table 11 gives partial pressures of various species, as well as total pressure over PuN.

By fitting the standard form of the vapor pressure versus temperature relation to the total pressure data given in Table 11, the following equation was obtained:

$$
\begin{aligned}
& \log \mathrm{P}_{\mathrm{T}}=2.7541-\frac{20329}{\mathrm{~T}}+0.89151 \log \mathrm{T} \\
& \left(\mathrm{P}_{\mathrm{T}} \text { in atm, } \mathrm{T} \text { in } \mathrm{K}\right)
\end{aligned}
$$

By using Eqs. 18-21 and fullowing a similar approach to that used for UN to correct for the heat of fusion, one obtains the following equations in the liquid region:

$$
\begin{aligned}
& \log \mathrm{P}_{\mathrm{Fu}}=5.07-\frac{18400}{\mathrm{~T}} \\
& \log \mathrm{P}_{\mathrm{N}_{2}}=3.38-\frac{15700}{\mathrm{~T}} \\
& \log \mathrm{P}_{\mathrm{PuN}}=7.38-\frac{28000}{\mathrm{~T}} \\
& \log \mathrm{P}_{\mathrm{Pu}_{2}}=5.44-\frac{25100}{\mathrm{~T}}
\end{aligned}
$$


TABLE 11. Low-Temperature Vapor Pressure of PuN

\begin{tabular}{|c|c|c|c|c|c|}
\hline $\begin{array}{c}\text { Temp, } \\
\mathrm{K}\end{array}$ & $\underset{\text { atm }}{\mathrm{P}_{\mathrm{Pu}}}$ & $\begin{array}{l}\mathrm{P}_{\mathrm{N}_{2}}, \\
\text { atm }\end{array}$ & $\mathrm{P}_{\mathrm{PuN}}^{\mathrm{Putm}}$ & $\begin{array}{l}\mathrm{P}_{\mathrm{Pu}_{2}}, \\
\text { atm }\end{array}$ & $\mathrm{P}_{\mathrm{T}}=\underset{\text { atm }}{\text { Total }}$ Pressure, \\
\hline 1600 & $6.70 \times 10^{-8}$ & $1.28 \times 10^{-8}$ & $1.50 \times 10^{-11}$ & $2.05 \times 10^{-12}$ & $7.99 \times 10^{-8}$ \\
\hline 1700 & $3.99 \times 10^{-7}$ & $7.57 \times 10^{-8}$ & $2.00 \times 10^{-10}$ & $2.68 \times 10^{-11}$ & $.4 .74 \times 10^{-7}$ \\
\hline 1800 & $1.94 \times 10^{-6}$ & $3.67 \times 10^{-7}$ & $2.00 \times 10^{-9}$ & $2.62 \times 10^{-10}$ & $2.31 \times 10^{-6}$ \\
\hline 1900 & $8.02 \times 10^{-6}$ & $1.50 \times 10^{-6}$ & $1.57 \times 10^{-8}$ & $2.02 \times 10^{-9}$ & $9.54 \times 10^{-6}$ \\
\hline 2000 & $2.87 \times 10^{-5}$ & $5.36 \times 10^{-6}$ & $1.00 \times 10^{-7}$ & $1.27 \times 10^{-8}$ & $3.42 \times 10^{-5}$ \\
\hline 2100 & $9.11 \times 10^{-5}$ & $1.69 \times 10^{-5}$ & $5.35 \times 10^{-7}$ & $6.71 \times 10^{-8}$ & $1.09 \times 10^{-4}$ \\
\hline 2200 & $2.60 \times 10^{-4}$ & $4.81 \times 10^{-5}$ & $2.46 \times 10^{-6}$ & $3.04 \times 10^{-7}$ & $3.11 \times 10^{-4}$ \\
\hline 2300 & $6.79 \times 10^{-4}$ & $1.25 \times 10^{-4}$ & $9.90 \times 10^{-6}$ & $1.21 \times 10^{-6}$ & $8.14 \times 10^{-4}$ \\
\hline 2400 & $1.63 \times 10^{-3}$ & $2.99 \times 10^{-4}$ & $3.55 \times 10^{-5}$ & $4.29 \times 10^{-6}$ & $1.97 \times 10^{-3}$ \\
\hline 2500 & $3.66 \times 10^{-3}$ & $6.69 \times 10^{-4}$ & $1.15 \times 10^{-4}$ & $1.37 \times 10^{-5}$ & $4.46 \times 10^{-3}$ \\
\hline 2600 & $7.72 \times 10^{-3}$ & $1.41 \times 10^{-3}$ & $3.39 \times 10^{-4}$ & $4.02 \times 10^{-5}$ & $9.51 \times 10^{-3}$ \\
\hline 2700 & $1.54 \times 10^{-2}$ & $2.80 \times 10^{-3}$ & $9.26 \times 10^{-4}$ & $1.09 \times 10^{-4}$ & $1.92 \times 10^{-2}$ \\
\hline 2800 & $2.93 \times 10^{-2}$ & $5.30 \times 10^{-3}$ & $2.35 \times 10^{-3}$ & $2.74 \times 10^{-4}$ & $3.72 \times 10^{-2}$ \\
\hline
\end{tabular}

By the use of the above equations along with an equation similar to Eq. 16 , partial pressures were estimated for various species as a function of temperature. These are listed in Table 12. For the data given in Table 12, the correlation between total pressure and temperature at higher temperatures was obtained as:

$$
\begin{aligned}
& \log \dot{\mathrm{P}}_{\mathrm{T}}=-9.7188-\frac{15234}{\mathrm{~T}}+3.984 \log \mathrm{T} \\
& \left(\mathrm{F}_{\mathrm{T}} \text { in atm, } \mathrm{T} \text { in. } \mathrm{K}\right)
\end{aligned}
$$

From the values given in Table 12, the normal boiling point of PuN was calculated to be $3509 \mathrm{~K}$.

Measurements of the vapor pressure of $\left(U_{0.8} \mathrm{Hu}_{0.2}\right) \mathrm{N}$ are not complete. Alexander and Ogden ${ }^{16}$ performed weight loss effusion measurements on various compositions from $80 \mathrm{~mol} \%$ PuN to $20 \mathrm{~mol} \%$ PuN. At each composition, they report that the systems appeared to behave ideally. Later work, 17 including high-temperature mass spectrometry, indicated that UN-PuN but not U-Pu could be treated ideally. Sheth and Leibowitzll fitted standard equations to the experimental data of Alexander and Ogden, ${ }^{16}$ which are as follows: 


$$
\begin{aligned}
& \log \mathrm{P}_{\mathrm{U}}=7.6619-\frac{30416}{\mathrm{~T}} \\
& \log \mathrm{P}_{\mathrm{Pu}}=5.2505-\frac{20893}{\mathrm{~T}} \\
& \log \mathrm{P}_{\mathrm{N}_{2}}=4.5797-\frac{21089}{\mathrm{~T}}
\end{aligned}
$$

According to Alexander and co-workers, ${ }^{2}$ vaporization of $\left(\mathrm{U}_{0.8} \mathrm{Pu}_{0.2}\right) \mathrm{N}$ is characterized mainly by a preferential loss of PuN as elemental plutonium and molecular nitrogen. They did not believe that any species other than $\mathrm{U}, \mathrm{Pu}$, and $\mathrm{N}_{2}$ is present. They considered it possible that UPu(g) is present; however, their estimates indicated that less UPu would be present than $\mathrm{Pu}_{2}$. Hence, in this study, for mixed nitrides, only $U, P u$, and $\mathrm{N}_{2}$ species are considered.

TABLE 12. Estimated Vapor Pressure of PuN

\begin{tabular}{cccccc}
\hline $\begin{array}{c}\text { Temp, } \\
\mathrm{K}\end{array}$ & $\begin{array}{c}\mathrm{P}_{\mathrm{Pu}}, \\
\mathrm{atm}\end{array}$ & $\begin{array}{c}\mathrm{P}_{\mathrm{N}_{2}}, \\
\mathrm{~atm}\end{array}$ & $\begin{array}{c}\mathrm{P}_{\mathrm{PuN}}, \\
\mathrm{atm}\end{array}$ & $\begin{array}{c}\mathrm{P}_{\mathrm{Pu}_{2}}, \\
\mathrm{~atm}\end{array}$ & $\begin{array}{c}\mathrm{P}_{\mathrm{T}}= \\
\text { Total Pressure, } \\
\mathrm{atm}\end{array}$ \\
\hline 2900 & $5.10 \times 10^{-2}$ & $8.84 \times 10^{-3}$ & $5.37 \times 10^{-3}$ & $5.96 \times 10^{-4}$ & $6.58 \times 10^{-2}$ \\
3000 & $8.31 \times 10^{-2}$ & $1.34 \times 10^{-2}$ & $1.13 \times 10^{-2}$ & $1.16 \times 10^{-3}$ & 0.11 \\
3500 & 0.63 & $7.54 \times 10^{-2}$ & 0.24 & $1.82 \times 10^{-2}$ & 0.96 \\
4000 & 2.86 & 0.28 & 2.42 & 0.14 & 5.71 \\
4500 & 9.32 & 0.75 & 14.52 & 0.72 & 25.31 \\
5000 & 23.94 & 1.69 & 60.83 & 2.59 & 89.05 \\
5500 & 51.83 & 3.26 & 196.35 & 7.41 & 258.85 \\
6000 & 98.65 & 5.65 & 521.35 & 17.80 & 643.46 \\
6500 & 170.06 & 8.99 & 1191.2 & 37.37 & 27407.6 \\
7000 & 271.22 & 13.40 & 2418.7 & 70.55 & 5016.3 \\
7500 & 406.44 & 18.92 & 4468.6 & 122.39 & 8448.7 \\
8000 & 579.06 & 25.60 & 7645.8 & 198.18 & \\
\hline
\end{tabular}

By use of Eqs. 28-30 and a similar approach to that used for UN and PuN to correct for heat of fusion, calculations were made to estimate partial pressures of various species over $\left(\mathrm{U}_{0.8} \mathrm{Pu}_{0.2}\right) \mathrm{N}$ in the liquid region. In comparison with UN and PuN, calculations indicated a much higher uranium partial pressure and a much lower plutonium partial pressure in the mixed nitride:. If UN and PuN in mixed nitride behave ideally, even in the liquid region, partial pressures of uranium and plutonium should be of the same order or similar to those in pure UN and PuN. Since low-temperature 
experimental work is not complete, it was decided not to extrapolate Alexander and Ogden's ${ }^{16}$ results into the liquid region. It was assumed that UN and PuN behave ideally in $\mathrm{U}-\mathrm{Pu}-\mathrm{N}$, and total pressure over $\left(\mathrm{U}_{0} .{ }_{8} \mathrm{Pu}_{0} .2\right) \mathrm{N}$ was estimated, using the following equation:

$$
\mathrm{P}_{\mathrm{T}}\left[\left(\mathrm{U}_{0.8} \mathrm{Pu}_{0.2}\right) \mathrm{N}\right] \approx 0.8 \mathrm{P}_{\mathrm{T}}[\mathrm{UN}]+0.2 \mathrm{P}_{\mathrm{T}}[\mathrm{PuN}]
$$

In Table 13, total pressure calculated using Eq. 31 is compared with total pressure obtained from Alexander and Ogden's ${ }^{16}$ experimental data. From Table 13, one can see that the data based on the assumption of ideal behavior between UN and PuN agree very well with the experimental data of Alexander and Ogden. 16

TABLE 13. Low-Temperature Vapor Pressure of $\left(\mathrm{U}_{0.8} \mathrm{Pu} \mathrm{u}_{0.2}\right) \mathrm{N}$

\begin{tabular}{lcc}
\hline $\begin{array}{c}\text { Temp, } \\
\mathrm{K}\end{array}$ & $\begin{array}{c}\text { Total Pressure, atm } \\
\text { (Calculated from ideal } \\
\text { solution assumption) }\end{array}$ & $\begin{array}{c}\text { Total Pressure, atm } \\
\text { (obtained from Ref. 16) }\end{array}$ \\
\hline 1600 & $1.60 \times 10^{-8}$ & $1.75 \times 10^{-8}$ \\
1700 & $9.57 \times 10^{-8}$ & - \\
1800 & $4.71 \times 10^{-7}$ & $5.98 \times 10^{-7}$ \\
1900 & $1.97 \times 10^{-6}$ & - \\
2000 & $7.24 \times 10^{-6}$ & $7.84 \times 10^{-6}$ \\
2100 & $2.38 \times 10^{-5}$ & - \\
2200 & $7.17 \times 10^{-5}$ & $6.87 \times 10^{-5}$ \\
2300 & $2.01 \times 10^{-4}$ & $3.72 \times 10^{-4}$ \\
2400 & $5.28 \times 10^{-4}$ & - \\
2500 & $1.32 \times 10^{-3}$ & - \\
2600 & $3.16 \times 10^{-3}$ & - \\
2700 & $7.25 \times 10^{-3}$ & - \\
2800 & $1.60 \times 10^{-2}$ &
\end{tabular}

The calculated total pressure data of Table. 13 were correlated with the temperature by the following relation:

$$
\begin{aligned}
& \log \mathrm{P}_{\mathrm{T}}=-29.84-\frac{13597}{\mathrm{~T}}+9.5388 \log \mathrm{T} \\
& \left(\mathrm{P}_{\mathrm{T}} \text { in atm, } \mathrm{T} \text { in } \mathrm{K}\right)
\end{aligned}
$$


Similarly, by use of Eq. 31 and the recommended liquid region data for UN and PuN given earlier, estimates of total pressure over $\left(\mathrm{U}_{0.8} \mathrm{Pu} 0.2\right) \mathrm{N}$ in the liquid region were made. These estimated values are in good agreement with the similar values for $U N$ and PuN and are given in Table 14.

TABLE 14. Estimated Vapor Pressure of $\left(\mathrm{U}_{0.8} \mathrm{Pu}_{0.2}\right)_{\mathrm{N}}$ in the Liquid Region

\begin{tabular}{cccc}
$\begin{array}{c}\text { Temp, } \\
\mathrm{K}\end{array}$ & $\begin{array}{r}\mathrm{P}_{\mathrm{T}}= \\
\text { Total Pressure, } \\
\text { atm }\end{array}$ & $\begin{array}{c}\text { Temp, } \\
\mathrm{K}\end{array}$ & $\begin{array}{c}\mathrm{P}_{\mathrm{T}}= \\
\text { Total Pressure } \\
\text { atm }\end{array}$ \\
\hline 3100 & 0.12 & 6000 & 828.87 \\
3500 & 0.93 & 6500 & 1763.7 \\
4000 & 6.83 & 7000 & 3385.1 \\
4500 & 33.18 & 7500 & 5980.5 \\
5000 & 119.07 & 8000 & 9875.5 \\
5500 & 341.83 & & \\
\hline
\end{tabular}

Fitting the standard form of the vapor pressure versus temperature relation to the total pressure data of Table 14 gives the following equation:

$$
\begin{aligned}
& \log \mathrm{P}_{\mathrm{T}}=3.0073-\frac{22886}{\mathrm{~T}}+0.98591 \log \mathrm{T} \\
& \left(\mathrm{P}_{\mathrm{T}} \text { in atm, } \mathrm{T} \text { in } \mathrm{K}\right) .
\end{aligned}
$$

From the values given in Table 14, at a total pressure of $1 \mathrm{~atm}$, the boiling point of $\left(\mathrm{U}_{0.8} \mathrm{Pu}_{0.2}\right) \mathrm{N}$ was calculated to be $3519 \mathrm{~K}$.

In Fig. 2, comparison is made between our calculated values for the total pressures of $\mathrm{UN}, \mathrm{PuN}$, and $\left(\mathrm{U}_{0.8} \mathrm{Pu}_{0.2}\right) \mathrm{N}$ as a function of inverse temperature in the entire temperacure range.

Thermal Conductivity of Nitride Fuels

As do carbide fuels, nitride fuels have a NaCl-type crystal structure, and therefore, display many metallic characteristics. At high temperatures, heat transfer is mainly electronic, obeying the Wiedmann-Franz law; that is, thermal conductivity is proportional to the product of temperature and electrical conductivity. At low temperature, a large phonon component will also be present. Alexander et $a l^{2}$ recently made a critical evaluation of the low-temperature thermal conductivity of nitride fuels. The same approach as was used for carbide fuels, 1 was used here to extrapolate their data beyond the melting point. This approach was an empirical rule proposed by Turnbull, 18 which states that the ratio of thermal conductivity of liquid to that of solid at the melting point is about $0.86 \pm 0.13$. In the absence of any knowledge on how thermal conductivity of nitrides would vary as a function of temperature beyond the melting point, a constant value should be used for liquid. thermal conductivity, as was done for carbide fuels. 


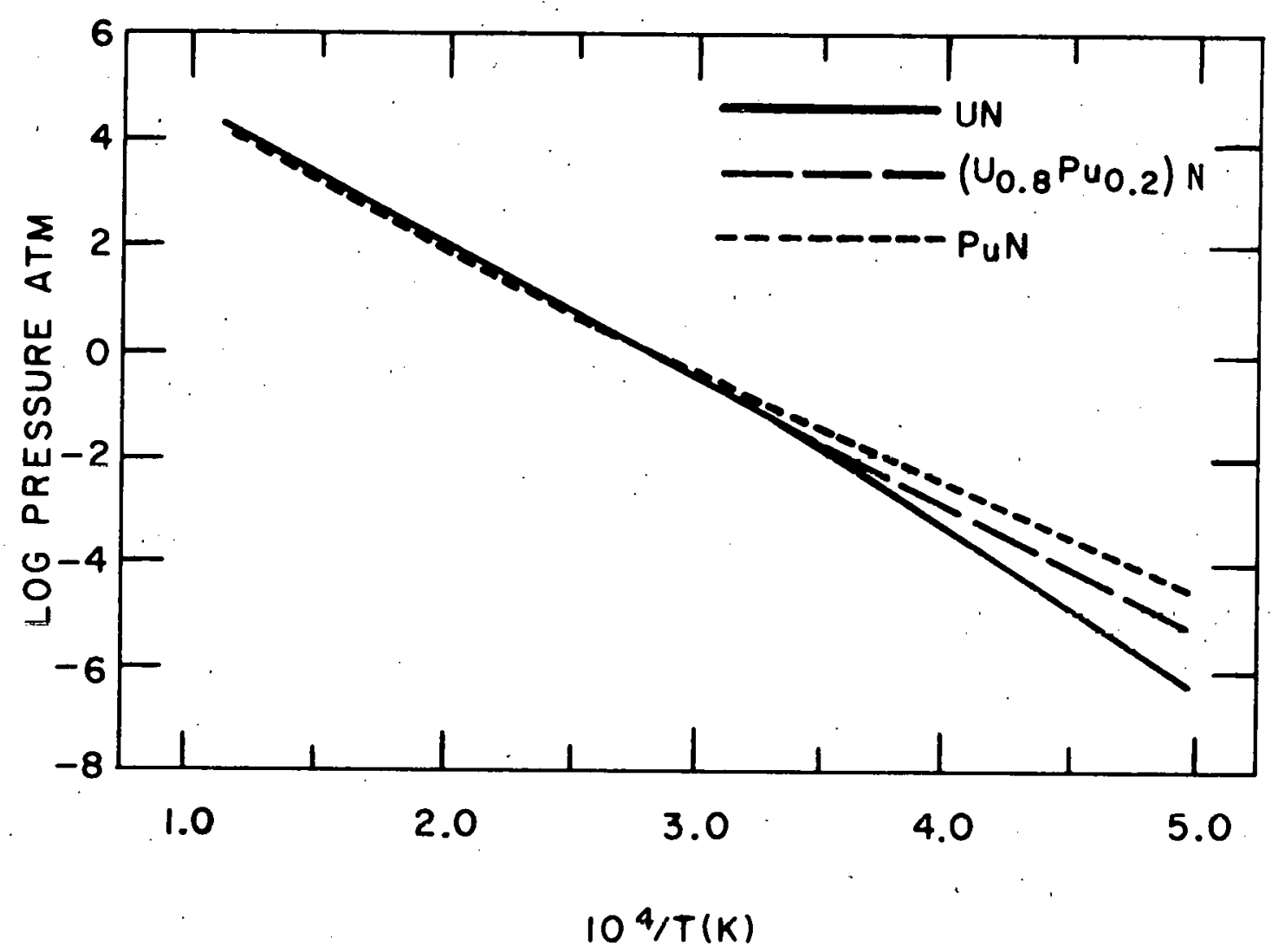

Fig. 2. Vapor Pressure of Nitride Fuels

Alexander and co-workers' 2 recommendations for thermal conductivity values of solid nitride fuels are given in Figs. 3-5 as a function of temperature. Since their data did not extend up to the recommended melting points of nitride fuels, we extrapolated their low-temperature data to determine thermal conductivity of solid nitride fuels at the melting point. Using this information and the empirical rule of Turnbull, we calculated thermal conductivity of liquid nitride fuels. Table 15 gives the thermal conductivity of nitride fuels, where $k_{s}$ represents thermal conductivity. in the solid state, $K_{\ell}$. represents thermal conductivity in the liquid state, and $\mathrm{T}_{\mathrm{m}}$ represents the melting point.

\section{Viscosity of Nitride Fuels}

Viscosity data for molten fuel materials are vary scarce. From experimental measurements, Tsai and olander ${ }^{19}$ had reported a viscosity of $9 \pm 1 \mathrm{cp}$ for $\mathrm{UO}_{2}$ at the melting point. Recently, Woodleyl9A measured viscosity of molten $\mathrm{UO}_{2}$ with an oscillating cup viscometer and reported a median viscosity of $4.2 \mathrm{cp}$. Using empirical rules, Chasanov ${ }^{2} 0$ recommended a mean value of about $5 \mathrm{cp}$ at the melting point for mixed-carbide fuel. Sheth and Leibowitzl used empirical rules given by Bird, Stewart, and Lightfoot ${ }^{21}$ and Andradae 22 to calculate viscosity of carbides of uranium and plutonium at the melting 


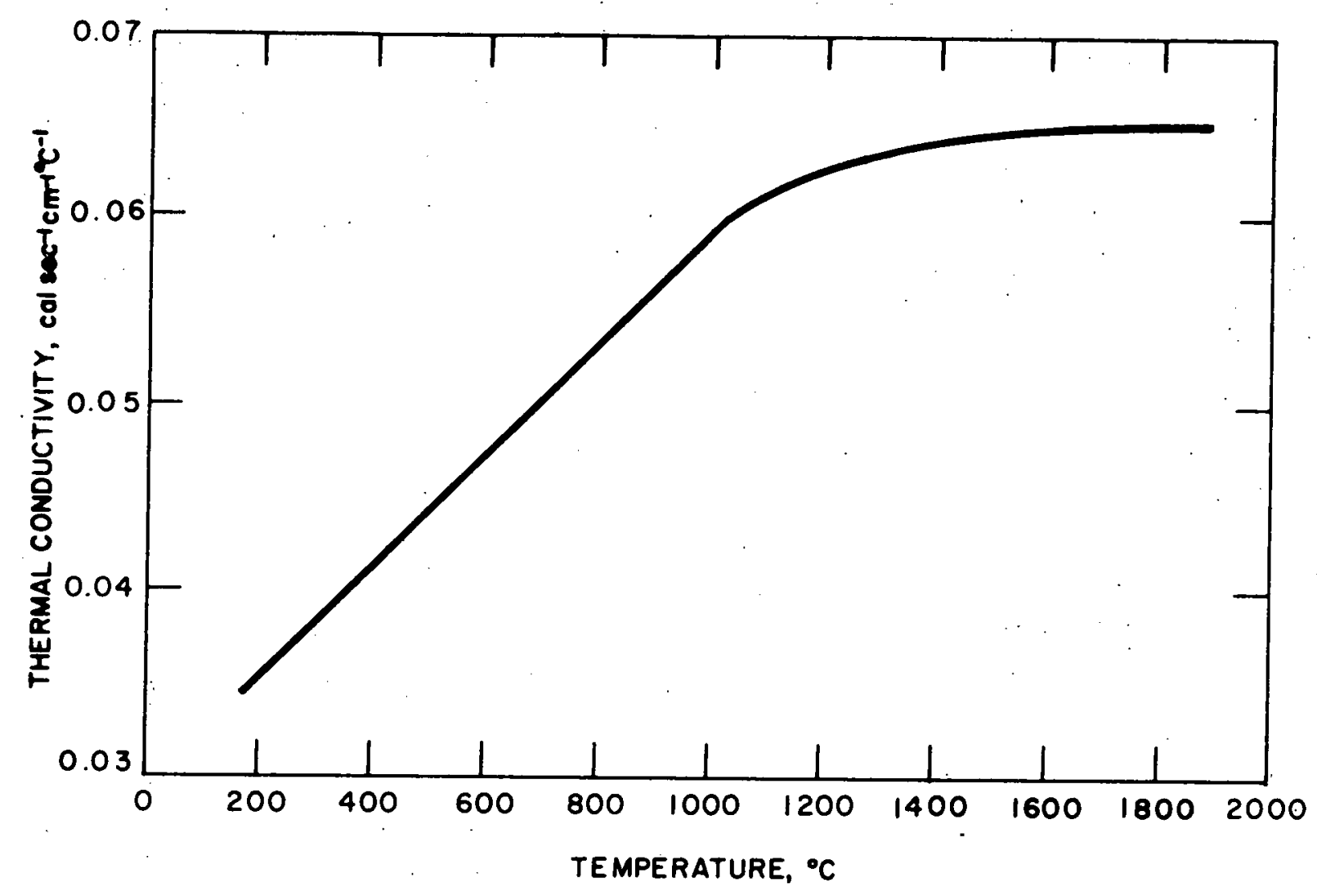

Fig. 3. Thermal Conductivity of $\mathrm{UN}^{2}$ (Below Melting Point)

point. The calculated and recommended values by Sheth and Leibowitzl agreed satisfactorily with Tsai and olander's value for molten $\mathrm{UO}_{2}$ and Chasanov's value for mixed carbide. Hence, it was decided to use Sheth and Leibowitz's approach to calculate the viscosity of nitride fuels.

Bird, Stewart, and Lightfoot ${ }^{21}$ presented the following empirical equation for viscosity of liquids:

$$
\mu \approx \frac{\mathrm{Nh}}{\mathrm{V}} \exp \left(3.8 \mathrm{~T}_{\mathrm{b}} / \mathrm{T}\right)
$$

where

$$
\begin{aligned}
\mathrm{H} & =\text { viscosity, poise }[\mathrm{g} /(\mathrm{cm})(\mathrm{sec})] \\
\mathrm{N} & =\text { Avogadro's number, }\left(6.023 \times 10^{23} \mathrm{molecules} / \mathrm{mol}\right) \\
\mathrm{V} & =\text { molar volume at temperature } \mathrm{T},(\mathrm{cc} / \mathrm{mol}) \\
\mathrm{T}_{\mathrm{b}} & =\text { normal boiling point, }(\mathrm{K}) \\
\mathrm{T} & =\text { temperature, }(\mathrm{K}) \\
\mathrm{h} & =\mathrm{Planck} \text { 's constant, }\left(6.624 \times 10^{-27} \mathrm{erg}-\mathrm{sec} \text { or } \mathrm{g} \cdot \mathrm{cm}^{2} / \mathrm{sec}\right)
\end{aligned}
$$




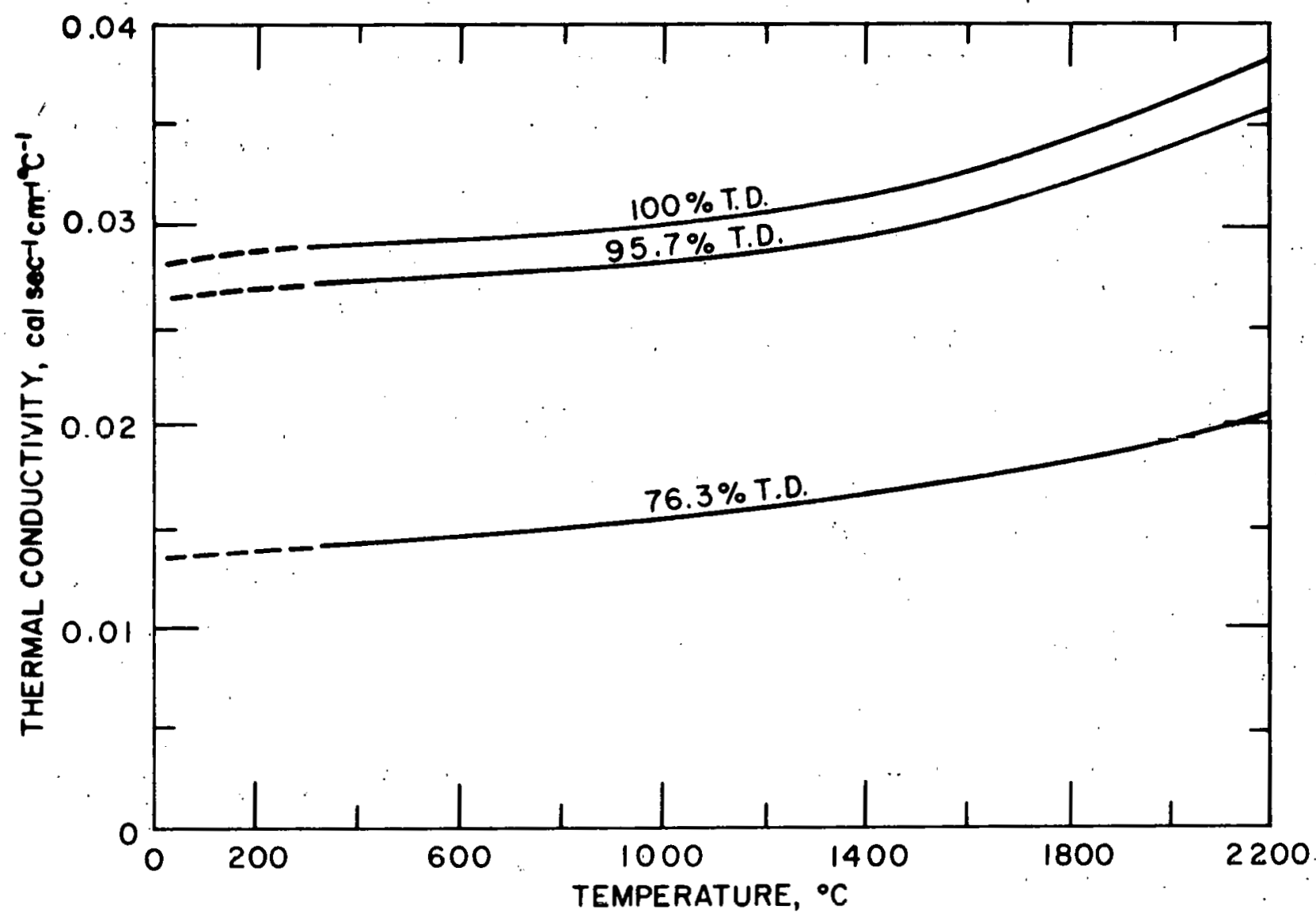

Fig. 4. Thermal Conductivity of PuN as a Function of Temperature and Density ${ }^{2}$ (Below Melting Point)

Andradae's ${ }^{22}$ equation, based on the quasi-crystalline structure of liquids, states that at the melting point:

$$
\mu=5.1 \times 10^{-4}\left(\mathrm{MT}_{\mathrm{m}}\right)^{1 / 2} / \mathrm{v}_{\mathrm{m}}^{2 / 3}
$$

where

$$
\begin{aligned}
\mathrm{M} & =\text { molecular weight } \\
\mathrm{T}_{\mathrm{m}} & =\text { melting point }(\mathrm{K}) \\
\mathrm{V}_{\mathrm{m}} & =\text { molar volume, }(\mathrm{cc} / \mathrm{mol})
\end{aligned}
$$

Usually, viscosity is related to an inverse of temperature by a logarithmic relation; however, in the present case the use of a constant value is recommended for the liquid region until more experimental data are available. By means of Eqs. 34 and 35 and other necessary data from this report, viscosity values at the melting point were calculated. These are listed in Table 16, along with the recommended values. 


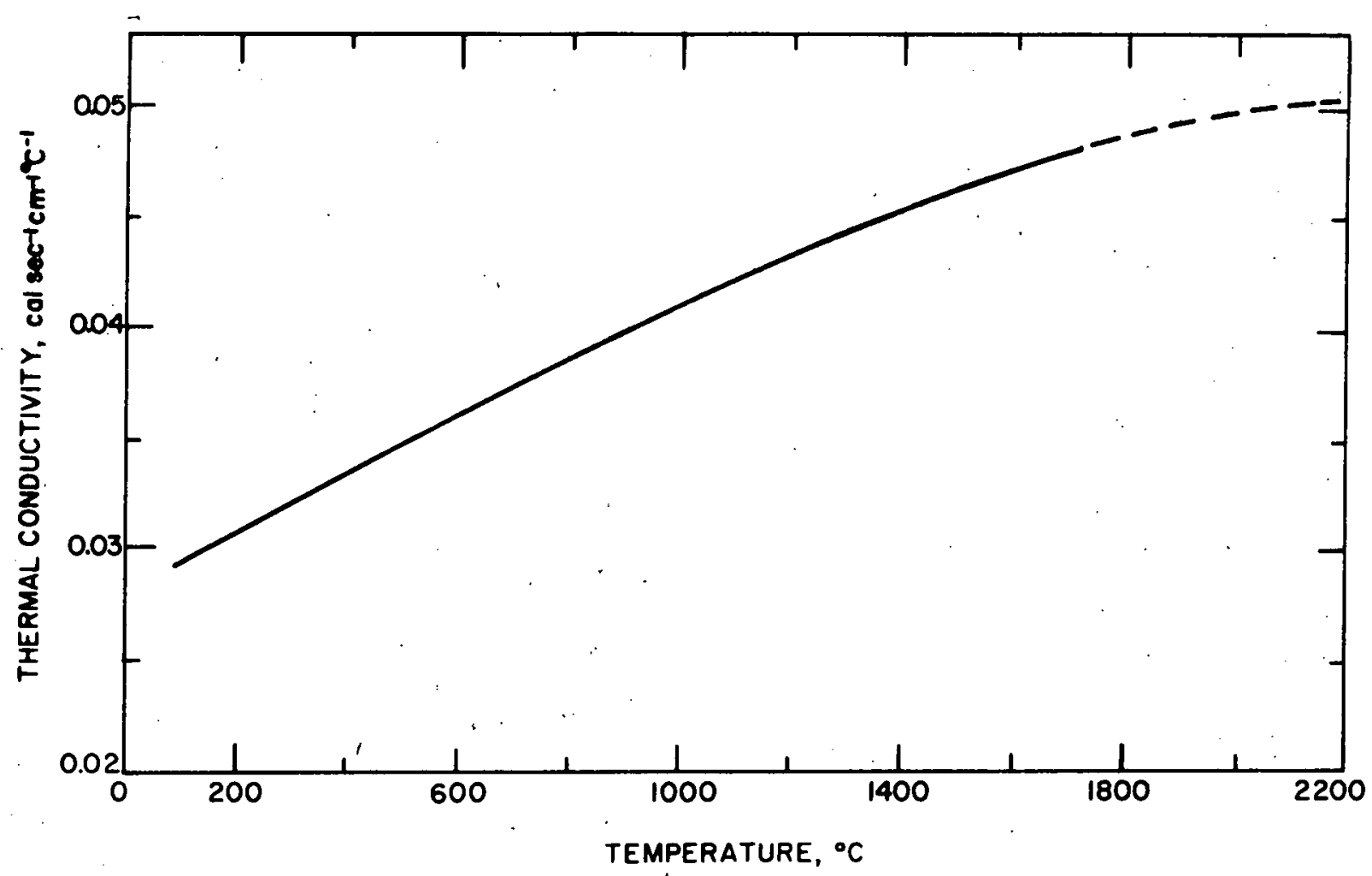

Fig. 5. Thermal Conductivity of $\left(\mathrm{U}_{0.8} \mathrm{Pu}_{0.2}\right) \mathrm{N}$ of 93\% Theoretical Density ${ }^{2}$ (Below Melting Point)

\section{Conclusions}

This report presents a set of preliminary results of various thermo-. physical and transport property values for candidate advanced nitride fuels which may reasonably be used until additional experimental or theoretical

TABLE 15. Thermal Conductivity of Nitride Fuels (100\% Theoretical Density)

\begin{tabular}{ccc}
\hline Compoind & $\begin{array}{c}\mathrm{K}_{\mathrm{s}} \text { at } \mathrm{T}_{\mathrm{m}}, \\
\text { r.a1 }(\mathrm{sec})(\mathrm{sm})\left({ }^{\circ} \mathrm{C}\right)\end{array}$ & $\begin{array}{c}\mathrm{K}_{\ell} \text { at } \mathrm{T}_{\mathrm{m}}, \\
\mathrm{cal} /(\mathrm{sec})(\mathrm{cm})\left({ }^{\circ} \mathrm{C}\right)\end{array}$ \\
\hline $\mathrm{UN}$ & 0.067 & 0.058 \\
$\mathrm{PuN}$ & 0.043 & 0.037 \\
$\left(\mathrm{U}_{0.8} \mathrm{Pu}_{0.2}\right) \mathrm{N}$ & $0.057^{\mathrm{a}}$ & 0.049 \\
\hline
\end{tabular}

${ }^{a}$ Alexander et $a l .{ }^{2}$ gave values for mixed nitride of only $93 \%$ of theoretical density, but suggested multiplication by 1.1 to estimate thermal conductivity for $100 \%$ theoretically dense samples. The value reported here for mixed nitride is obtained using this suggestion. 
TABLE 16. Viscosity of Nitride Fuels

\begin{tabular}{cccc}
\hline Compound & $\begin{array}{c}\mu_{\mathrm{m}} \\
\text { (centipo1se) } \\
\text { Calcd. from Eq. 34 }\end{array}$ & $\begin{array}{c}\mu_{\mathrm{m}} \\
\text { (centipoise) } \\
\text { Calcd. from Eq. 35 }\end{array}$ & $\begin{array}{c}\mu_{\mathrm{m}} \\
\text { (centipoise) } \\
\text { Recommended }\end{array}$ \\
\hline UN & 1.5 & 5.7 & 4 \\
PuN & 1.9 & 5.3 & 4 \\
$\left(\mathrm{U}_{0.8} \mathrm{Pu}_{0.2}\right) \mathrm{N}$ & 1.4 & 5.7 & 4 \\
\hline
\end{tabular}

data are available. For the liquid region, almost all the property values were estimated, and an attempt was made to use estimation techniques similar to thoșe used for carbide fuels. Recommended data are given in tabular form and in terms of standard equations. No attempt was made to optimize the form of the equations. Throughout, efforts were made to preserve internal consistency, consistency with other properties, and consistency with lowtemperature data. (that is, data below the melting point). Due care should be taken when using these data.

As was found in work on carbide fuels, this work has revealed a significant gap in the information for nitride fuels in the liquid region. Experimental work and additional analysis are needed.

\section{ACKNOWLEDGMEN'TS}

The authors wish to express their appreciation to Drs. R. Ackermann, C. Alexander, P. Blackburn, M. Tetenbaum, and G. Winslow for helpful suggestions and discussions. 


\section{REFERENCES}

1. A. Sheth and L. Leibowitz, Equation of State and Transport Properties of Uranium and Plutonium Carbides in the Liquid Region, ANL-AFP-11 (1975).

2. C.A. Alexander et al., Thermodynamic and Transport Characteristics of Actinide-Nitride Fuels, BMI-X-659 (June 1975).

3. D. Fee and C.E. Johnson, Phase Equilibria and Melting Point Data for Advanced Fuel Systems, ANL-AFP-10 (June 1975).

4. G.H. Winslow, Argonne National Laboratory, private communication (1975):

5. G.H. Winslow, Thermomechanical Properties of Real Materials: The Thermal Expansions of $\mathrm{UO}_{2}$ and $\mathrm{ThO}_{2}$, High Temp. Sci. 3,361 (1971).

6. O.H. Hougen, K.M. Watson, and R.A. Ragatz, Chemical Process Principles, Part II, Thermodynamics, 2nd ed., p. 569-576, John Wiley and Sons, Inc., New York (1959).

7. D. Miller, "A Critical Review of the Properties of Materials at High Temperatures and Pressures Significant for Fast Reactor Safety," Proc. of the Conference on Safety, Fuels, and Core Design in Large Fast Reactors, Oct. 11-14, 1965, ANL-7120, p. 641-653 (1966).

8. P. Blackburn, Argonne National Laboratory, private communication (1975).

9. K.A. Gingerich, Vaporization of Uranium Mononitride and Heat of Sublimation. of Uranium, J. Chem. Phys. 51, 4433 (1969).

10. K.A. Gingerich, J. Chem. Phys. 47, 2192 (1967).

11. A. Sheth and L. Leibowitz, Equation-of-State for Advanced Fuels: Interim Report, ANL-AFP-2 (October 1974).

12. R.A. Kent and J.A. Leary, Mass Spectrometric Studies of Plutonium Compounds at High Temperatures: IV. The Vaporization of PuN, High Temp. Sci. 1, 176 (1969).

13. U-Pu Nitride Fuels for LMFBR Applications, BMI-1868, Sect. A (July 1969).

14. D.L. Keller, Annual Report, BMI-1845 p. A-60 (1968).

15. M.H. Rand et al., Plutonium: Physicochemical Properties of Its Compounds and Alloys, At. Energy Rev. 4 (1), 1-112 (1966).

16. C.A. Alexander and J.S. Ogden, Developments in the Technology of Nuclear Fuels during August 1967-68, Annual Report, BMI-1848 (1968).

17. C.A. Alexander et al., Thermophysical Properties of (U,Pu)N, Nuc1. Met., Met. Soc. AIME 17, 95 (1970). 
18. A.G. Turnbul1, The Thermal Conductivity of Molten Salts, II: Theory and Results for Pure Salts, Aust. J. Applied Sci. 12, 324 (1961).

19. H.C. Tsal and D.R. Olander, Trans. Am. Nucl. Soc. 15, 211.(1972).

19A. R.E. Woodley, The Viscosity of Molten Uranium Dloxide, J. Nuc1. Mater., 50, $103(1974)$.

20.: M.G. Chasanov, Argonne National Laboratory, private communication (1974).

21. R.B. Bird, W.E. Stewart, and E.N. Lightfoot, Transport Phenomena, p. 26-29, John Wiley and Sons, Inc., New York (1960).

22. J.R. Partington, An Advanced Treatise on Physical Chemistry, Vol.2, The Froperties of Liquids, p. 108, Longmans, Green and Company, New York, Toronto (1951). 